\title{
Duurzame inzetbaarheid en pensionering in de overheid en het onderwijs
}

Citation for published version (APA):

Fouarge, D., de Grip, A., \& Montizaan, R. M. (2013). Duurzame inzetbaarheid en pensionering in de overheid en het onderwijs. ROA. ROA Reports No. 010 https://doi.org/10.26481/umarep.2013010

Document status and date:

Published: 01/01/2013

DOI:

10.26481/umarep.2013010

Document Version:

Publisher's PDF, also known as Version of record

\section{Please check the document version of this publication:}

- A submitted manuscript is the version of the article upon submission and before peer-review. There can be important differences between the submitted version and the official published version of record.

People interested in the research are advised to contact the author for the final version of the publication, or visit the DOI to the publisher's website.

- The final author version and the galley proof are versions of the publication after peer review.

- The final published version features the final layout of the paper including the volume, issue and page numbers.

Link to publication

\footnotetext{
General rights rights.

- You may freely distribute the URL identifying the publication in the public portal. please follow below link for the End User Agreement:

www.umlib.nl/taverne-license

Take down policy

If you believe that this document breaches copyright please contact us at:

repository@maastrichtuniversity.nl

providing details and we will investigate your claim.
}

Copyright and moral rights for the publications made accessible in the public portal are retained by the authors and/or other copyright owners and it is a condition of accessing publications that users recognise and abide by the legal requirements associated with these

- Users may download and print one copy of any publication from the public portal for the purpose of private study or research.

- You may not further distribute the material or use it for any profit-making activity or commercial gain

If the publication is distributed under the terms of Article $25 \mathrm{fa}$ of the Dutch Copyright Act, indicated by the "Taverne" license above, 


\section{Duurzame inzetbaarheid en pensionering in de overheid en het onderwijs}

Didier Fouarge

Andries de Grip

Raymond Montizaan

ROA-R-2013/10 


\section{Colofon}

(C) Researchcentrum voor Onderwijs en Arbeidsmarkt (ROA). Niets uit deze uitgave mag op enige manier worden verveelvoudigd zonder voorafgaande schriftelijke toestemming van de directeur van het ROA.

\section{Researchcentrum voor Onderwijs en Arbeidsmarkt}

School of Business and Economics

Maastricht University

\section{Vormgeving}

ROA secretariaat, Maastricht

\section{Verkoop}

Researchcentrum voor Onderwijs en Arbeidsmarkt email: secretary-roa-sbe@maastrichtuniversity.nl website: www.roa.nl

ISBN: 978-90-532I-520-3 


\section{Inhoud}

Voorwoord $\quad$ v

I Inleiding

2 Pensioenverwachtingen van werknemers 3

2.I Inleiding 3

2.2 Verwachte pensioenleeftijd 4

2.3 Risicobereidheid en pensioen 8

2.4 Persoons- en persoonlijkheidskenmerken en spaargedrag I4

2.5 Persoonlijkheidskenmerken per sector $\quad$ I5

2.6 Conclusie 20

3 Vitaliteitsbeleid $\quad 23$

3.I Inleiding 23

3.2 Op vitaliteit gericht HR-beleid 23

3.3 HR-beleid rond duurzame inzetbaarheid van oudere werknemers 25

3.4 Informatie over pensioenen 29

3.5 Conclusie 3I

4 Werknemersgedrag en HR-beleid 33

4.I Inleiding 33

4.2 Verwachte pensioenleeftijd en HR-beleid van werkgevers 33

4.3 Kans op training naar leeftijd 35

$\begin{array}{ll}4.4 \text { Conclusie } & 37\end{array}$

5 Conclusies $\quad 39$

5.I Pensioenverwachtingen 39

5.2 Vitaliteitsbeleid 4I

5.3 Werknemersgedrag en HR-beleid 42

5.4 Beleidsaanbevelingen $\quad 42$ 
Bijlage A: Op vitaliteit gericht HR-beleid, percentage organisaties naar sector

Bijlage B: Op oudere medewerkers gericht HR-beleid, naar sector 


\section{Voorwoord}

Dit onderzoek wordt gesubsidieerd door Instituut GAK en het Ministerie van Sociale Zaken en Werkgelegenheid. ABP heeft naast de administratieve dataverstrekking bijgedragen door respondenten te benaderen met het verzoek om te participeren in dit onderzoek en door een jaarlijkse updatemailing te versturen ten behoeve van de respons. De onderzoeksresultaten zijn gebaseerd op gekoppelde werkgevers-werknemerspaneldata die bestaan uit een combinatie van survey- en administratieve data die zijn verzameld in $201 \mathrm{I}$ en 2012. 



\section{Inleiding}

Het kabinet Rutte-Asscher heeft afspraken gemaakt over een versnelde verhoging van de AOW-leeftijd, zodat deze in 2018 op 66 jaar zal liggen en in 202I op 67 jaar. Werknemers zullen zich daarom moeten instellen op een situatie waarin zij langer moeten doorwerken. Tegelijkertijd zorgt de verhoging van de pensioenleeftijd ervoor dat de duurzame inzetbaarheid van werknemers een steeds belangrijkere plaats krijgt op de HR-agenda. Werkgevers moeten zich daarbij niet alleen instellen op een situatie waarin er meer 6o-plussers aan het werk zijn, maar ook op een grotere variatie in de uittredingsleeftijd als gevolg van de introductie van meer flexibele pensioenregelingen, zoals bijvoorbeeld het ABP Keuzepensioen. Werkgevers zullen zich daarom moeten beraden op welke wijze zij hierop gaan reageren. Daarbij gaat het om de vraag op welke manier zij uiteenlopende groepen werknemers gemotiveerd, gezond en productief tot op hogere leeftijd aan het werk kunnen houden.

Wat vergen de versoberingen in het pensioenstelsel en het bevorderen van duurzame inzetbaarheid van werknemers en werkgevers?

Deze vraag staat centraal in dit rapport waarin verslag wordt gedaan van de belangrijkste uitkomsten van het onderzoek dat wij gedaan hebben in de verschillende sectoren die zijn aangesloten bij het Pensioenfonds ABP.

Voor het beantwoorden van de onderzoeksvraag maken wij gebruik van twee datasets. De eerste dataset bestaat uit een combinatie van administratieve data en survey data die zijn gebaseerd op twee enquêtes die in 2011 en 2012 gehouden zijn onder een representatieve steekproef van werknemers in de leeftijd van 35 tot 65 jaar die werkzaam zijn in de sectoren die het ABP bedient. Deze werknemerssurvey bevat informatie over de werkmotivatie, het takenpakket, de verwachte pensioenrechten en het verwachte inkomen na pensionering en de pensioenvoorzieningen die de werknemers in deze sectoren zelf hebben getroffen.

De benadering van de werknemers vond in twee stappen plaats. In de eerste stap werd er door het pensioenfonds naar 57.300 werknemers een brief gestuurd met het verzoek om deel te nemen aan het onderzoek en hun e-mailadres op te sturen. In de tweede stap werden de mensen die hun e-mailadres hadden toegestuurd door het ROA per e-mail benaderd met daarin een link naar de internetenquête. In 201 I bedroeg het 
responspercentage $14 \%$. In 2012 hebben in totaal 6.200 werknemers de enquête ingevuld. Dat is een responspercentage van $\mathrm{II}_{\mathrm{O}} \%$.

De tweede dataset is gebaseerd op een werkgeversenquête die een gedetailleerd beeld geeft van de HR instrumenten die de werkgevers inzetten om oudere medewerkers langer met plezier inzetbaar te houden. De enquête die eveneens is uitgezet in $20 \mathrm{II}$ en 2012 bevat onder andere vragen over het gebruik van HR instrumenten op het terrein van training, arbeidsvoorwaarden, interne promotie, incidentele beloning, coaching, werkzekerheid, participatie, leerklimaat en functionerings- en beoordelingsgesprekken, alsook over het gevoerde beleid ten aanzien van de arbeidsomstandigheden, verzuimbegeleiding en de mogelijkheid tot werkaanpassingen. Bovendien wordt in de werkgeversenquête expliciet aandacht besteed aan het karakter van het gevoerde beleid, voorop op de vraag of er op de genoemde terreinen een ad hoc of een structureel HR-beleid gevoerd wordt.

De werkgeversenquête is per e-mail verstuurd, met daarin een link naar de internetenquête naar circa 2.500 werkgevers binnen de verschillende overheidssectoren en het onderwijs. In 20 II bedroeg de responspercentage $29 \%$, terwijl die in 2012 ruim $31 \%$ was (circa 800 organisaties hebben de enquête ingevuld).

Dit rapport is als volgt opgebouwd. In hoofdstuk 2 wordt een overzicht gegeven van de pensioenverwachtingen van de werknemers in de sector overheid en onderwijs. Daarbij wordt er dieper ingegaan op de invloed van verschillende persoonlijkheidskenmerken op de pensioenverwachtingen en het spaargedrag van werknemers. Dit is belangrijk omdat er bij het verstrekken van informatie over pensionering door de toegenomen flexibiliteit in het pensioensysteem steeds meer maatwerk is vereist. Dan is het bijvoorbeeld belangrijk om te weten welke mensen hun pensioen te rooskleurig inschatten, welke mensen langer willen doorwerken en in welke mate zij bereid zijn om risico te nemen ten aanzien van de hoogte van hun pensioen. In hoofdstuk 3 wordt het door de werkgevers gevoerde personeelsbeleid in kaart gebracht. Daarbij gaat het om de vraag welke HR-instrumenten er worden ingezet en hoe werkgevers hun ouderenbeleid vormgeven. Hoofdstuk 4 gaat vervolgens in op de vraag in hoeverre de HR-instrumenten die werkgevers hanteren een effect hebben op de leeftijd waarop hun eigen medewerkers met pensioen denken te gaan, alsook op de vraag in welke mate werkgevers bereid zijn om HR-beleid in te zetten voor de inzetbaarheid van oudere medewerkers. In hoofdstuk 5 vatten wij de onderzoeksresultaten samen. 


\section{Pensioenverwachtingen van werknemers}

\subsection{Inleiding}

Werknemers worden in de afgelopen jaren voortdurend geconfronteerd met veranderingen in hun pensioenrechten. Door de toegenomen flexibiliteit in het pensioensysteem wordt individueel maatwerk in de communicatie over de mogelijkheden om uit te treden en de implicaties van de versoberingen van het pensioenstelsel voor de pensioenverwachtingen steeds belangrijker. Om de communicatie over pensionering richting werknemers te optimaliseren is het daarom van groot belang om een beter beeld te krijgen over hoe verschillende mensen over hun pensioen denken, en om te bepalen welke mensen denken langer te zullen doorwerken, in welke mate zij bereid zijn om risico te nemen ten aanzien van de hoogte van hun pensioen, en hoeveel zij zelf voor hun pensioen bijsparen. ${ }^{\mathrm{T}}$

In dit hoofdstuk wordt aandacht besteed aan de rol die persoonlijkheidskenmerken hebben bij de vorming van pensioenverwachtingen. Dit doen wij aan de hand van een korte set vragen die het mogelijk maken om de belangrijkste persoonlijkheidskenmerken van mensen op een eenvoudige wijze in kaart te brengen. Dit hoofdstuk laat zien dat persoonlijkheidskenmerken een belangrijke bepalende factor zijn voor de pensioenverwachtingen en dat het dus loont om door middel van enkele korte vragen aan klanten / werknemers een beeld te vormen van hun persoonlijkheid. Op deze manier kan er voor worden gezorgd dat het communicatiebeleid over de pensioenproblematiek sterk inspeelt op de individuele voorkeuren en verwachtingen.

I. De studies van De Grip et al. (20II) en Montizaan en Vendrik (20I3) laten zien dat de versoberingen in het pensioenstelsel ook negatieve effecten kunnen hebben op de mentale gezondheid en baantevredenheid. De laatstgenoemde studie toont aan dat deze effecten voor een groot deel worden gedreven door sociale vergelijkingen tussen collega's die wel of niet geconfronteerd worden met een versobering in hun pensioenrechten. 


\subsection{Verwachte pensioenleeftijd}

Figuur 2.I geeft een overzicht van de verwachte pensioenleeftijd van de werknemers in de verschillende overheids- en onderwijssectoren. Daarbij dient te worden opgemerkt dat het hierbij gaat om de subjectieve percepties van werknemers en niet om hun feitelijke (toekomstige) uittredeleeftijd. De gemiddelde verwachte pensioenleeftijd in 2012 was 65 jaar. Daarmee is de verwachte pensioenleeftijd één jaar gestegen ten opzichte van 20II. De sectorale verschillen geven hetzelfde beeld als in 2OII (Fouarge et al., 20II). ${ }^{2}$ Zo denken werknemers in de sectoren wetenschappelijk onderwijs, onderzoek en wetenschapsbeleid, academische ziekenhuizen en het hoger beroepsonderwijs op iets latere leeftijd te stoppen met werken. Degenen die werkzaam zijn in het primair onderwijs of bij de politie of defensie (burgerpersoneel) denken daarentegen duidelijk eerder uit te treden. Het verschil in de gemiddelde verwachte pensioenleeftijd tussen het wetenschappelijk onderwijs, onderzoek en wetenschapsbeleid en het defensie burgerpersoneel bedraagt ruim 2 jaar en 9 maanden.

\section{Figuur 2.1}

Verwachte pensioenleeftijd per sector (in jaren)

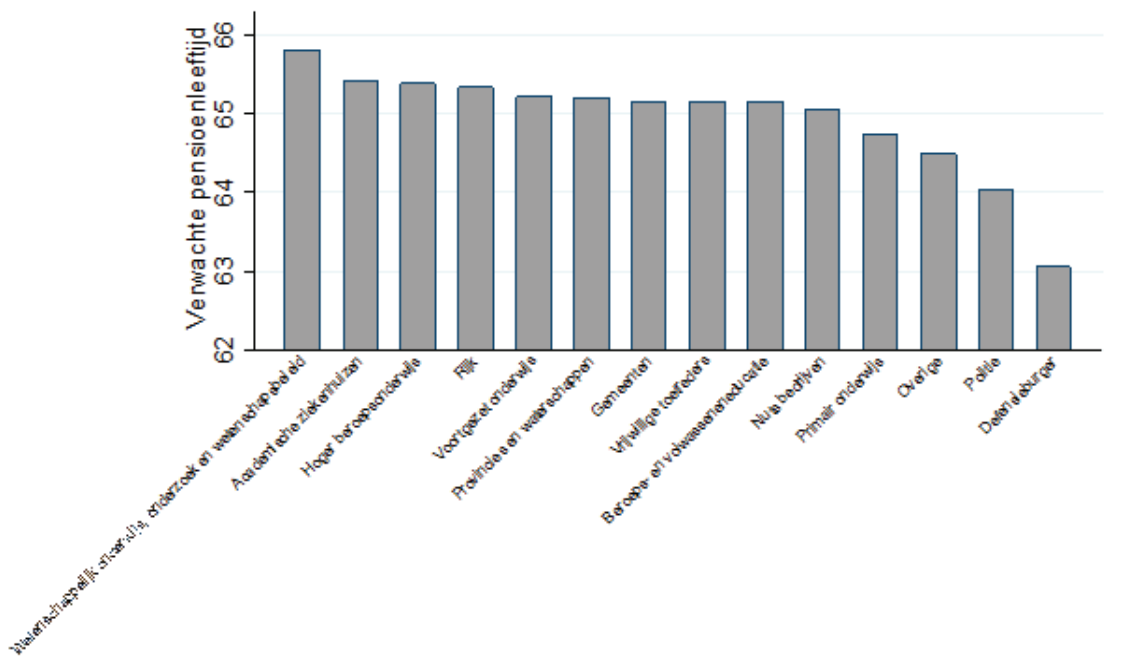

Tabel 2.I toont aan in welke mate de verwachte pensioenverwachtingen samenhangen met verschillende persoons- en persoonlijkheidskenmerken (zie tekstbox 2.I voor een uitleg van de verschillende persoonlijkheidsindicatoren). Het blijkt dat werknemers in de leeftijd van 45-54 jaar gemiddeld vier maanden eerder denken uit te treden dan degenen in de leeftijdsgroep van 35-44 jaar. Mensen in de leeftijdsgroep van

2. Fouarge, D., A. de Grip \& R. Montizaan (20II). Pensioenverwachtingen en personeelsbeleid. Verslag van de ROA enquête 20II. Maastricht: ROA-R-20II/9. 
55-64 jaar denken zelfs II maanden eerder met werken te kunnen stoppen. Het feit dat ouderen eerder met pensioen denken te kunnen gaan kan daarbij deels worden verklaard door de stapsgewijze verhoging van de AOW-gerechtigde leeftijd en door het feit dat zij hogere pensioenrechten hebben dan jongere generaties (o.a. door de invoering van het middelloonstelsel), of omdat jongere werknemers hun productiviteit en gezondheid op oudere leeftijd mogelijk overschatten. Ook blijkt dat hoger opgeleiden gemiddeld vier maanden langer denken door te werken dan middelbaar opgeleiden, terwijl werknemers die fulltime werkzaam zijn gemiddeld 3 maanden later met pensioen verwachten te gaan dan iemand die maar 3 dagen per week werkt. Mensen die getrouwd zijn denken daarentegen 5 maanden eerder uit te treden. Niet gerapporteerde analyses waar in meer detail is gekeken naar mogelijke verschillen in de effecten van de burgerlijke staat voor mannen en vrouwen op de verwachte pensioenleeftijd laten verder zien dat getrouwde vrouwen 9 maanden eerder denken uit te treden dan ongehuwde vrouwen, terwijl getrouwde mannen maar een halve maand eerder denken uit te treden dan ongehuwde mannen.

Tabel 2.1

Relatie tussen verwachte pensioenleeftijd en persoons- en persoonlijkheidskenmerken

\begin{tabular}{|c|c|}
\hline \multicolumn{2}{|l|}{ Persoonskenmerken } \\
\hline Leeftijd 45-54 & -- \\
\hline Leeftijd 55-64 & -- \\
\hline Laag opgeleid & 0 \\
\hline Hoog opgeleid & ++ \\
\hline Overheid & ++ \\
\hline Onderwijs & ++ \\
\hline Jaarloon (In) & 0 \\
\hline Deeltijdfactor & ++ \\
\hline Pensioenjaren & 0 \\
\hline Geslacht & 0 \\
\hline Getrouwd / partner & -- \\
\hline \multicolumn{2}{|c|}{ Persoonlijkheidskenmerken } \\
\hline Algemene risicobereidheid & -- \\
\hline Tijdsvoorkeur & ++ \\
\hline Optimisme & 0 \\
\hline Gebrekkige financiele kennis & 0 \\
\hline Emotionele stabiliteit & ++ \\
\hline Extravert & 0 \\
\hline Openheid voor ervaring & ++ \\
\hline Inschikkelijk & -- \\
\hline Zorgvuldig & 0 \\
\hline
\end{tabular}

Tabel 2.I laat verder zien dat verschillende persoonlijkheidskenmerken de leeftijd waarop iemand met pensioen denkt te gaan beïnvloeden. Daarbij onderscheiden we allereerst twee economische persoonlijkheidskenmerken: iemands risicobereidheid en 
tijdsvoorkeur. Iemand die geen enkel risico wil nemen denkt 8 maanden later uit te treden dan iemand die zeer bereid is om risico's te nemen. Mensen die niet bereid zijn om van dingen af te zien om daar later voordeel van te hebben (de zogenaamde "tijdsvoorkeur") denken daarentegen 5 maanden eerder uit te treden dan degenen die zeer bereid is om dit te doen.

\section{Tekstbox 2.1}

Uitleg persoonlijkheidskenmerken

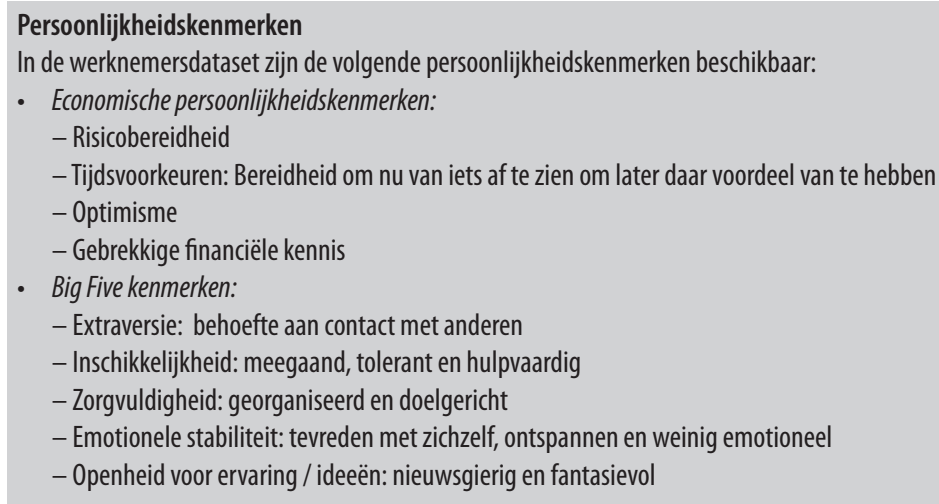

De risicobereidheid en tijdsvoorkeuren zijn gemeten aan de hand van de volgende vragen:

In hoeverre bent u van nature iemand die bereid is om risico's te nemen, of iemand die juist risico's probeert te vermijden? In hoeverre bent u van nature iemand die bereid is om vandaag van iets af te zien om daar later voordeel van te hebben?

U kunt uw antwoord aangeven op een schaal van 0 tot 10, waarbij 0 betekent dat u helemaal niet bereid bent om risico's te nemen en 10 dat u zeer bereid bent om risico's te nemen.

De mate waarin mensen optimistisch van karakter zijn is gemeten met behulp van de LOT-R schaal van Scheier en Carver (1994). De LOT-R bevat 6 vragen die worden gebruikt om iemands optimisme te meten, en wordt gemeten op een vijfpuntschaal die van nul (helemaal oneens) tot vier (helemaal mee eens) gaat. Van de drie gebruikte items zijn drie op een positieve manier geformuleerd en drie op een negatieve manier. Negatief geformuleerde items moeten voor het scoren omgeschaald worden. Onze optimismeschaal is bepaald door de gemiddelde score te nemen van de zes items.

De indicator voor een gebrekkige financiële kennis wordt ontleend aan de US Health and Retirement Study en is gevalideerd door Lusardi en Mitchell (2007) en Lusardi en Mitchell (2008) en Van Rooij et al. (2011). De indicator wordt bepaald met behulp van de volgende drie vragen:

Stel, u heeft 100 euro op uw spaarrekening en de rente is $2 \%$ per jaar, hoeveel geld denkt u dat u op uw spaarrekening zou hebben na 5 jaar als u geen geld opnam van deze rekening? Minder dan 102 euro / Exact 102 euro / Meer dan 102 euro 


\section{Tekstbox 2.1 (vervolg)}

Uitleg persoonlijkheidskenmerken

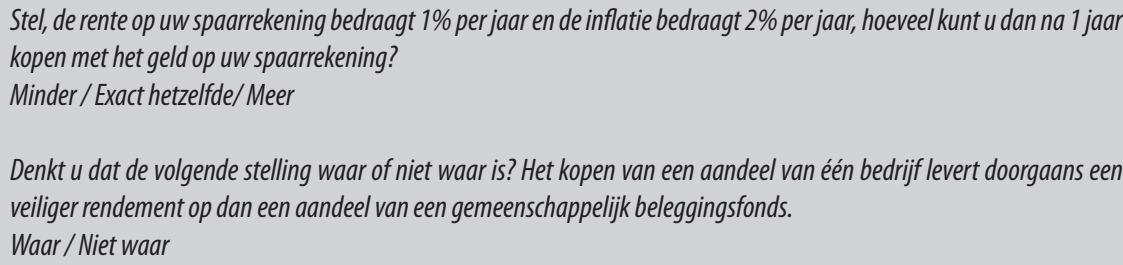

Stel, de rente op uw spaarrekening bedraagt $1 \%$ per jaar en de inflatie bedraagt $2 \%$ per jaar, hoeveel kunt u dan na 1 jaar kopen met het geld op uw spaarrekening?

Minder/Exact hetzelfde/Meer

Denkt u dat de volgende stelling waar of niet waar is? Het kopen van een aandeel van één bedrijf levert doorgaans een veiliger rendement op dan een aandeel van een gemeenschappelijk beleggingsfonds.

Waar/Niet waar

Respondenten worden als financieel deskundig beschouwd als zij alle drie vragen correct hebben beantwoord. $0 \mathrm{p}$ basis van deze maatstaf kan $14,1 \%$ van alle respondenten als financieel ondeskundig worden beschouwd.

De Big Five wordt gemeten aan de hand van 15 vragen. Deze vragenlijst is gevalideerd door Mcmanus en Furnham (2006) en Furnham et al. (2003). De Big Five theorie is onder psychologen algemeen geaccepteerd als het belangrijkste persoonlijkheidsmodel. De Big Five is een theoretisch neutraal model die is gebaseerd op persoonsbeschrijvende woorden. Er zijn vele woorden waarmee men iemands persoonlijkheid kan beschrijven. De makers van de Big Five hebben al deze woorden verzameld en vervolgens geanalyseerd welke woorden relatief vaak voor dezelfde persoon worden gebruikt. Door factoranalyse zijn zij uiteindelijk tot vijf karaktertrekken uitgekomen die kunnen worden opgevat als de vijf grootste gemene delers van alle karaktereigenschappen. In totaal worden er drie vragen per karaktertrek gesteld om vast te stellen wat voor een karakter een persoon heeft. Voor dit onderzoek nemen wij de gemiddelde score per karaktertrek. De vijf karaktertrekken zijn:

\section{Emotionele stabiliteit}

Mensen die hoog scoren op dit domein maken zich minder vaak zorgen, en voelen zich relatief vaak gelukkig of veilig. Mensen die laag scoren zijn daarentegen makkelijk uit het veld te slaan en raken in paniek bij stress-situaties.

\section{Inschikkelijkheid}

Inschikkelijkheid staat voor de oriëntatie van het individu op de ervaringen, belangen en doelen van anderen. Personen die hoog scoren op deze schaal zijn vaker hulpvaardig, bescheiden en vaker geneigd tot samenwerken. Personen die laag scoren op deze schaal zijn echter egocentrisch en werken liever alleen.

\section{Zorgvuldigheid}

De zorgvuldigheidsschaal meet in hoeverre mensen in staat zijn om actief te plannen en te organiseren. Personen die hoog scoren op deze schaal zijn doelmatig, ambitieus, ordelijk en systematisch.

\section{Extraversie}

De extraversie schaal meet in hoeverre iemand het leuk vindt om actief bezig te zijn met andere personen. Mensen die hoog scoren op deze schaal zijn meer sociaal, houden van het gezelschap van anderen en zijn assertiever, actiever en spraakzamer dan introverte mensen. Introverte mensen scoren laag op de extraversieschaal.

\section{Openheid}

De openheid schaal meet de verbeeldingskracht, de voorkeur voor variatie en de intellectuele nieuwsgierigheid van mensen. Mensen die hoog scoren op de openheid schaal zijn dan ook vaak nieuwsgierig. Hun ervaringswereld is doorgaans rijker en gevarieerder dan die van mensen die laag scoren.

De Big Five wordt tegenwoordig vaak toegepast in de praktijk. Zo dienen deze vragen vaak als basis van veel psychologische testen bij personeelswerving en selectie, en worden zij vaak ingezet voor het leveren van maatwerk bij trainingen, coaching en het aanpakken van analyses en het aanpakken van arbeidsconflicten. 
De negatieve relatie tussen risicobereidheid en de verwachte pensioenleeftijd wijst er op dat degenen die meer risico durven te lopen ondanks de voortdurende versoberingen van het pensioenstelsel toch eerder met pensioen durven te gaan. (zie ook Chetty, 2006). ${ }^{3}$ De positieve relatie tussen iemands bereidheid om nu af te zien van dingen om daar later voordeel van te hebben en de verwachte pensioneringsleeftijd laat zien dat mensen die bereid zijn om meer op te geven om daarvan in de toekomst profijt te hebben beter kunnen inspelen op de negatieve effecten van de versoberingen in het pensioenstelsel dan mensen die moeite hebben om leukere dingen uit te stellen. Immers, zij verwachten al op een hogere leeftijd uit te treden waarop zij ook een hoger pensioen zullen krijgen.

De effecten van de Big Five persoonlijkheidskenmerken zijn eveneens sterk. Zo verwacht iemand die een zeer open karakter (score van vijf op de schaal) heeft ruim I2 maanden later met pensioen te gaan dan iemand die zeer gesloten is (score van één op de schaal), terwijl een hoge emotionele stabiliteit leidt tot een verhoging van de pensioenleeftijd met II maanden. Mensen die meer inschikkelijk zijn verwachten daarentegen bijna II maanden eerder met pensioen te gaan.

\subsection{Risicobereidheid en pensioen}

De verhoging van de AOW-leeftijd en de verlaagde pensioenopbouw zal er toe leiden dat werknemers zullen zich moeten instellen op een situatie waarin zij langer moeten doorwerken. Deze ontwikkelingen betekenen echter ook dat werknemers steeds meer verantwoordelijkheid zullen moeten nemen om er voor te zorgen dat zij later voldoende pensioen zullen hebben. In zoverre valt te verwachten dat werknemers in de toekomst meer zullen gaan investeren in commerciële pensioenproducten die onder de derde pijler van het Nederlandse pensioensysteem vallen. Men kan daarbij denken aan lijfrente, levensverzekeringen, banksparen en beleggingsproducten. Deze verschillende pensioenproducten in de derde pijler zijn echter complex en de verschillen tussen de verschillende producten zijn vaak moeilijk zichtbaar.

Daarnaast wordt er steeds meer nadruk gelegd op de beleggingsstrategieën van pensioenfondsen en wordt de roep op meer inspraak voor werknemers groter. Onder andere zouden zij meer inspraak moeten krijgen in ethische kwesties, maar ook in de mate waarin het pensioenfonds risico mag lopen bij haar beleggingsstrategie. Ook deze tendens zal er waarschijnlijk voor gaan zorgen dat werknemers meer verantwoordelijk zullen worden voor hoe hun pensioen zal worden opgebouwd.

De vraag is vervolgens in hoeverre werknemers eigenlijk bereid zijn om risico's te nemen ten aanzien van de hoogte van hun pensioen. Figuur 2.2 geeft een beeld van de algemene risicobereidheid van werknemers in de sector overheid en onderwijs, terwijl

3. Chetty, R. (2006), A New Method of Estimating Risk Aversion, American Economic Review, Vol 95, I82I-I834. 
Figuur 2.3 hun bereidheid om risico's te nemen met betrekking tot de hoogte van hun eigen pensioen laat zien. De algemene risicobereidheid is gebaseerd op de surveyvraag:

In hoeverre bent $u$ van nature iemand die bereid is om risico's te nemen, of iemand die juist risico's probeert te vermijden?

En de risicobereidheid met betrekking tot het pensioen is gemeten aan de hand van de surveyvraag:

Mensen kunnen zich op verschillende gebieden anders gedragen. Hoe zou u uw bereidheid om risico's te nemen op de volgende gebieden inschatten?

\section{Uw pensioen}

In beide figuren is de risicobereidheid gemeten op een schaal van o tot IO, waarbij o betekent dat iemand helemaal niet bereid is om risico's te nemen en Io dat iemand zeer bereid is om risico's te nemen. De gemiddelde algemene risicobereid is 4,9 . De risicobereidheid ten aanzien van de hoogte van het pensioen is met een score van 3,7 significant lager. Opvallend is dat bijna één op de tien werknemers zelfs geen enkel risico wil nemen voor hun pensioen.

Iemands bereidheid om risico's te nemen hangt sterk af van persoons- en persoonlijkheidskenmerken. Tabel 2.2 laat zien dat de bereidheid om risico te nemen ten aanzien van de hoogte van het pensioen afneemt met leeftijd. Werknemers in de leeftijd van 55-65 jaar hebben een gemiddelde score die 0,67 lager is dan degenen die jonger zijn dan 45 jaar. Werknemers die drie dagen in de week werken hebben een score die o,I4 lager is dan degenen die fulltime werken en mannen zijn meer bereid risico te nemen: zij scoren gemiddeld o,I7 hoger dan vrouwen. 
HOOFDSTUK 2

Figuur 2.2

Algemene risicobereidheid

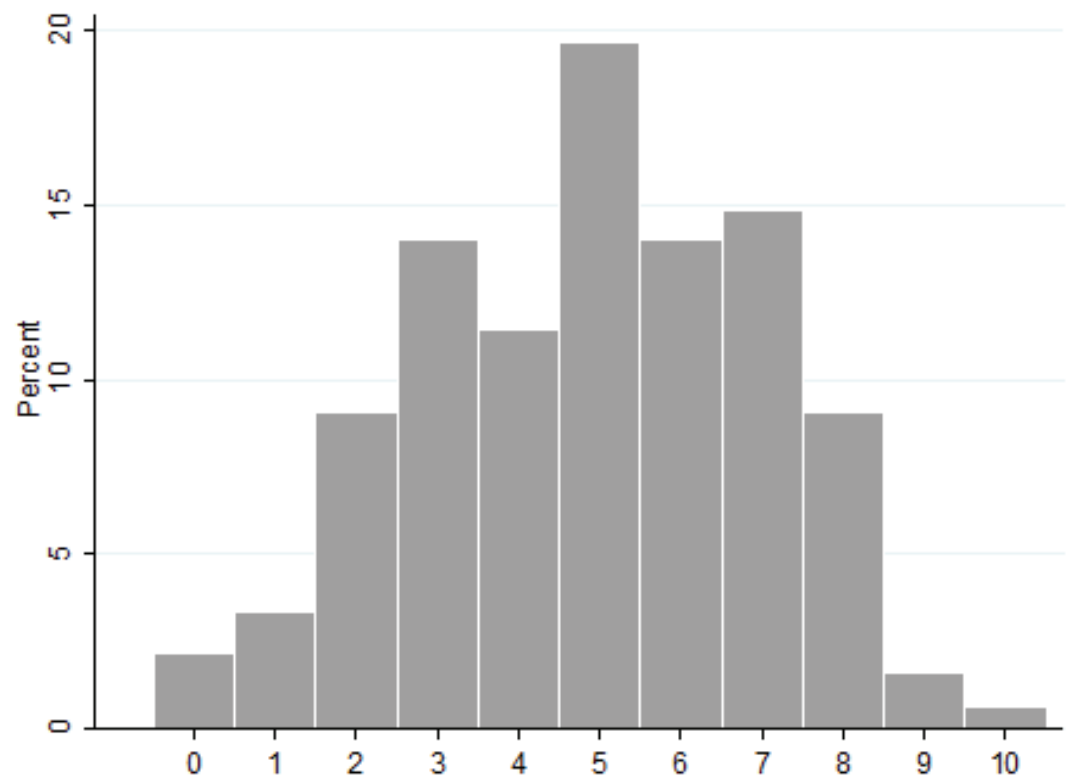

$0=$ helemaal niet bereid om risico's te nemen; $10=$ zeer bereid om risico's te nemen

Figuur 2.3

Risicobereidheid met betrekking tot de hoogte van het latere pensioen

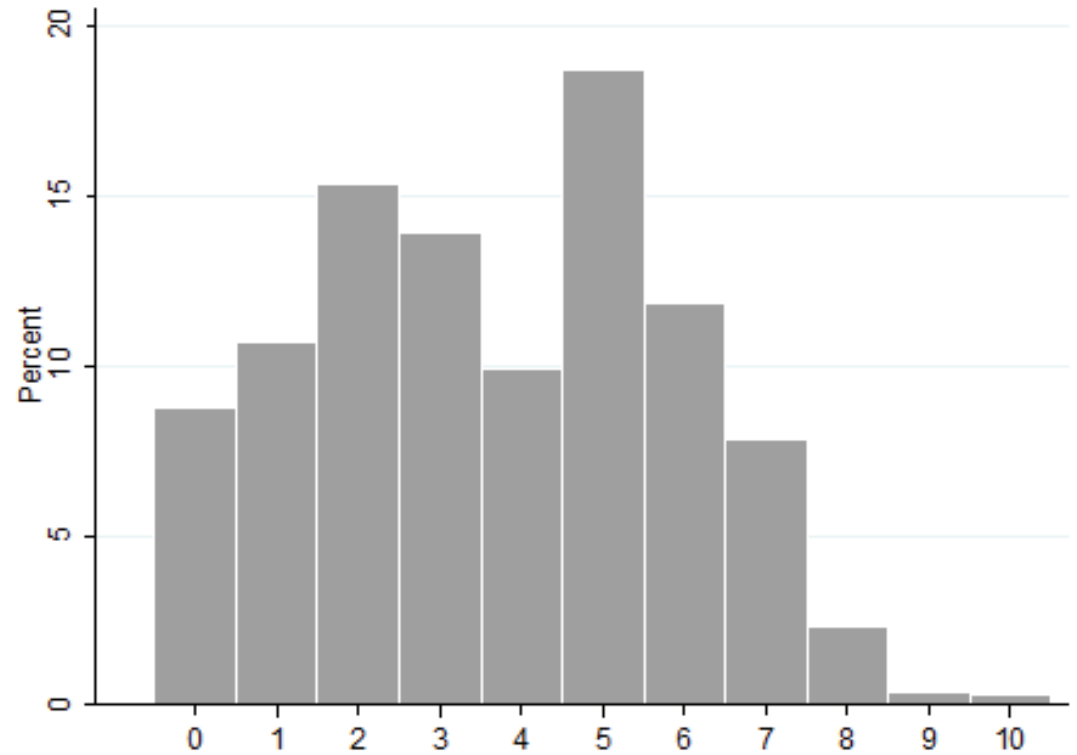

$\mathrm{o}=$ helemaal niet bereid om risico's te nemen; $10=$ zeer bereid om risico's te nemen 
Zoals te verwachten valt is iemands risicobereidheid met betrekking tot de hoogte van het latere pensioen sterk gecorreleerd met de algemene risicobereidheid: één standaarddeviatie stijging in de algemene risicobereidheid leidt tot een 2,58 hogere score voor de risicobereidheid ten aanzien van de hoogte van het pensioen. Ook een grotere bereidheid om dingen nu op te geven om daar in de toekomst profijt van te hebben, optimisme en extraversie resulteert in grotere risicobereidheid ten aanzien van de hoogte van het pensioen. Zorgvuldige mensen zijn daarentegen minder bereid om risico's te nemen voor hun pensioen.

\section{Tabel 2.2}

Bereidheid om risico te nemen met betrekking tot de pensioenhoogte

$\begin{array}{ll}\text { Persoonskenmerken } & -- \\ \text { Leeftijd } 45-55 & -- \\ \text { Leeftijd 55-65 } & 0 \\ \text { Laag opgeleid } & 0 \\ \text { Hoog opgeleid } & 0 \\ \text { Overheid } & 0 \\ \text { Onderwijs } & 0 \\ \text { Jaarloon (In) } & - \\ \text { Deeltijdfactor } & 0 \\ \text { Pensioenjaren } & ++ \\ \text { Geslacht } & 0 \\ \text { Getrouwd / partner } & \\ \text { Persoonlijkheidskenmerken } & ++ \\ \text { Algemene risicobereidheid } & ++ \\ \text { Tijdsvoorkeur } & ++ \\ \text { Optimisme } & 0 \\ \text { Gebrekkige financiële kennis } & 0 \\ \text { Emotionele stabiliteit } & 0 \\ \text { Extravert } & -- \\ \text { Openheid voor ervaring } & 0 \\ \text { Inschikkelijk } & ++ \\ \text { Zorgvuldig } & 0 \\ \text { OLS regressie resultaten. }++=\text { significant positief effect; -- = significant negatief effect; - = licht } \\ \text { significant negatief effect; o = geen significant effect } \\ \end{array}$

Zoals eerder werd aangegeven levert pensioengeld dat niet wordt belegd (waardoor het risico dus beperkt is) gemiddeld genomen een minder hoge pensioenuitkering op. Een belangrijke vraag die hieruit volgt is of mensen nog steeds bereid zijn om een laag risico te nemen voor hun pensioen als zij op de hoogte zijn van deze trade-off. Om dat vast te kunnen stellen hebben wij een extra vraag opgenomen waarin de afweging tussen risico en de hoogte van de pensioenuitkering wordt uitgelegd:

Indien uw pensioenfonds een zeer klein risico neemt bij haar beleggingsstrategie (meer sparen dan beleggen), dan zal het gemiddeld verwacht pensioen relatief laag zijn, en is de 
kans dat u een hoog pensioen krijgt zeer klein. Anderzijds als uw pensioenfonds een groter risico neemt (meer beleggen dan sparen), dan zal uw gemiddeld verwacht pensioen relatief hoog zijn, maar wordt de kans dat u een zeer laag of zeer hoog pensioen krijgt groter doordat de opbrengsten onzekerder worden.

Als uw pensioenfonds u zou vragen welke beleggingsstrategie zij zouden moeten hanteren, hoe zou deze er dan volgens u uit moeten zien? (zeer klein risico, klein risico, gemiddeld risico, groot risico, zeer groot risico).

Tabel 2.3

Verschil in bereidheid om risico te lopen ten aanzien van de hoogte van het pensioen: met uitleg t.o.v. zonder uitleg

\begin{tabular}{ll} 
Persoonskenmerken & ++ \\
Leeftijd 45-54 & ++ \\
Leeftijd 55-65 & 0 \\
Laag opgeleid & 0 \\
Hoog opgeleid & 0 \\
Overheid & -- \\
Onderwijs & 0 \\
Jaarloon (In) & ++ \\
Deeltijdfactor & 0 \\
Pensioenjaren & 0 \\
Geslacht & 0 \\
Getrouwd / partner & -- \\
Persoonlijkheidskenmerken & 0 \\
Algemene risicobereidheid & 0 \\
Tijdsvoorkeur & - \\
Optimisme & -- \\
Gebrekkige financiële kennis & ++ \\
Emotionele stabiliteit & 0 \\
Extravert & -- \\
Openheid voor ervaringen & 0 \\
Inschikkelijk & \\
Zorgvuldig & \\
OLS regressie resultaten. ++ = significant positief effect; -- = significant negatief effect; o = geen \\
significant effect & \\
\hline & \\
&
\end{tabular}

Tabel 2.3 laat zien dat bepaalde groepen werknemers hun antwoord aanpassen als ze uitleg hebben gekregen over de trade-off tussen risico en het te verwachten rendement. Oudere werknemers, fulltimers, en emotionele stabiele werknemers zijn na de uitleg meer bereid om risico's te nemen ten aanzien van de hoogte van hun pensioen. Anderzijds zijn degenen die werkzaam zijn in het onderwijs minder bereid om risico's te lopen. Weinig verrassend is dat mensen met een hogere risicobereidheid eveneens minder gevoelig zijn voor de uitleg over de trade-off tussen het nemen van risico en rendement. De negatieve correlatie voor de verschillen in de antwoorden voor en na 
de uitleg bij de mensen met een gebrekkige financiële kennis en het meer openstaan voor nieuwe ervaringen valt ook intuïtief te verklaren. Men kan immers verwachten dat werknemers met een gebrekkige financiële kennis ook meer moeite hebben met de uitleg over de trade-off tussen het nemen van risico's en rendement. Ook mensen die meer open staan voor nieuwe ervaringen zijn na de uitleg minder bereid om risico te lopen met hun pensioen.

Figuur 2.4 laat verder duidelijk zien dat het leeftijdspatroon in de bereidheid om risico te nemen ten aanzien van het eigen pensioen precies omdraait door de uitleg over de trade-off tussen risico en rendement. Zonder uitleg willen oudere werknemers minder risico lopen ten aanzien van hun pensioen dan jongere werknemers. Na uitleg willen oudere werknemers echter juist meer risico nemen. Het lijkt er dus op dat ouderen meer waarde hechten aan een hoger gemiddeld verwacht rendement dan jongeren, wat mogelijk kan worden verklaard door het feit dat hun pensioen ook tastbaarder is voor hen. Een andere mogelijke reden hiervoor is dat jongeren niet beseffen dat hun beleggingshorizon langer is.

\section{Figuur 2.4}

Bereid om risico te nemen met de hoogte van het pensioen naar leeftijd

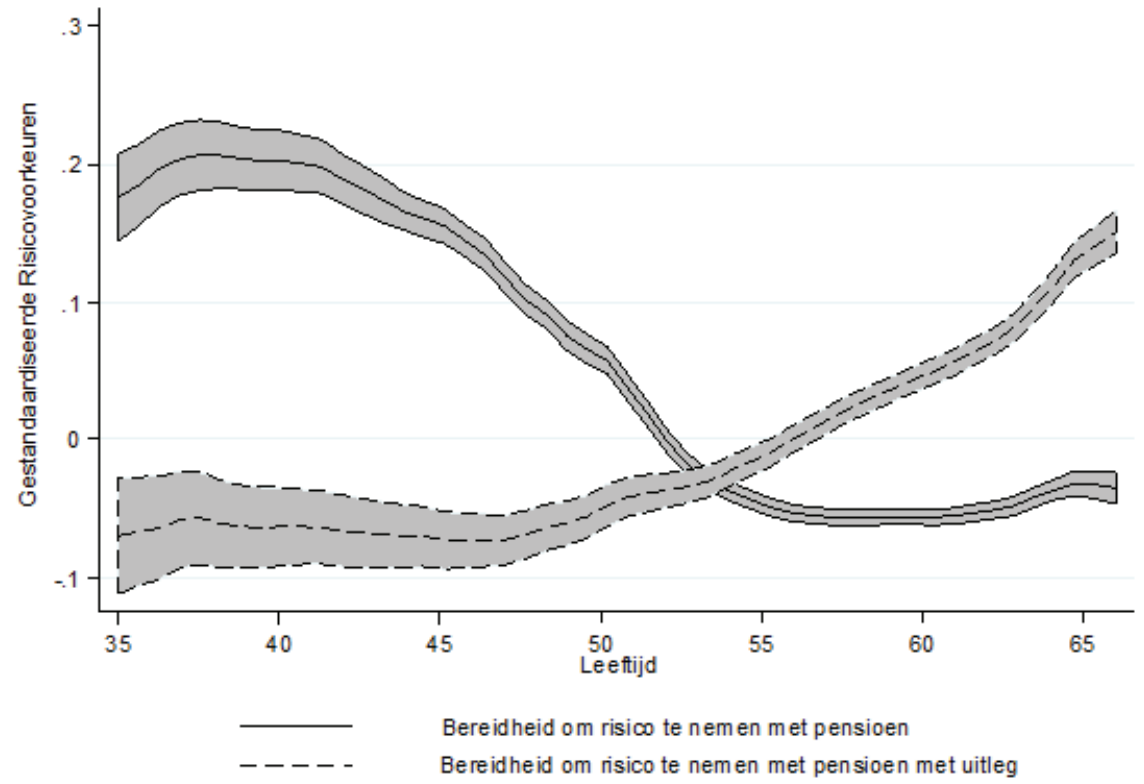




\subsection{Persoons- en persoonlijkheidskenmerken en spaargedrag}

De versoberingen van de pensioenrechten in de eerste en tweede pijler van het pensioensysteem zorgen er voor dat werknemers meer privaat moeten gaan bijsparen om voldoende inkomen te hebben als zij vervroegd met pensioen willen gaan. Tabel 2.4 laat zien wat de belangrijkste determinanten zijn van het spaargedrag in de derde schil van het pensioensysteem. Het blijkt dat het bijsparen sterk afhangt van de financiële situatie van werknemers. Werknemers met een hoger inkomen sparen meer bij, terwijl werknemers die meer pensioenjaren hebben opgebouwd juist minder vaak bijsparen voor hun latere pensioen. Ook valt het op dat mannen en hoger opgeleiden vaker besluiten om extra te sparen voor hun pensioen. Opvallend is ook dat werknemers van middelbare leeftijd meer sparen (kans om bij te sparen is 9\% groter) dan zowel oudere werknemers als jongere werknemers.

\section{Tabel 2.4}

De relatie tussen persoonlijkheidskenmerken en de wijze waarop iemand zelf spaart voor het latere pensioen

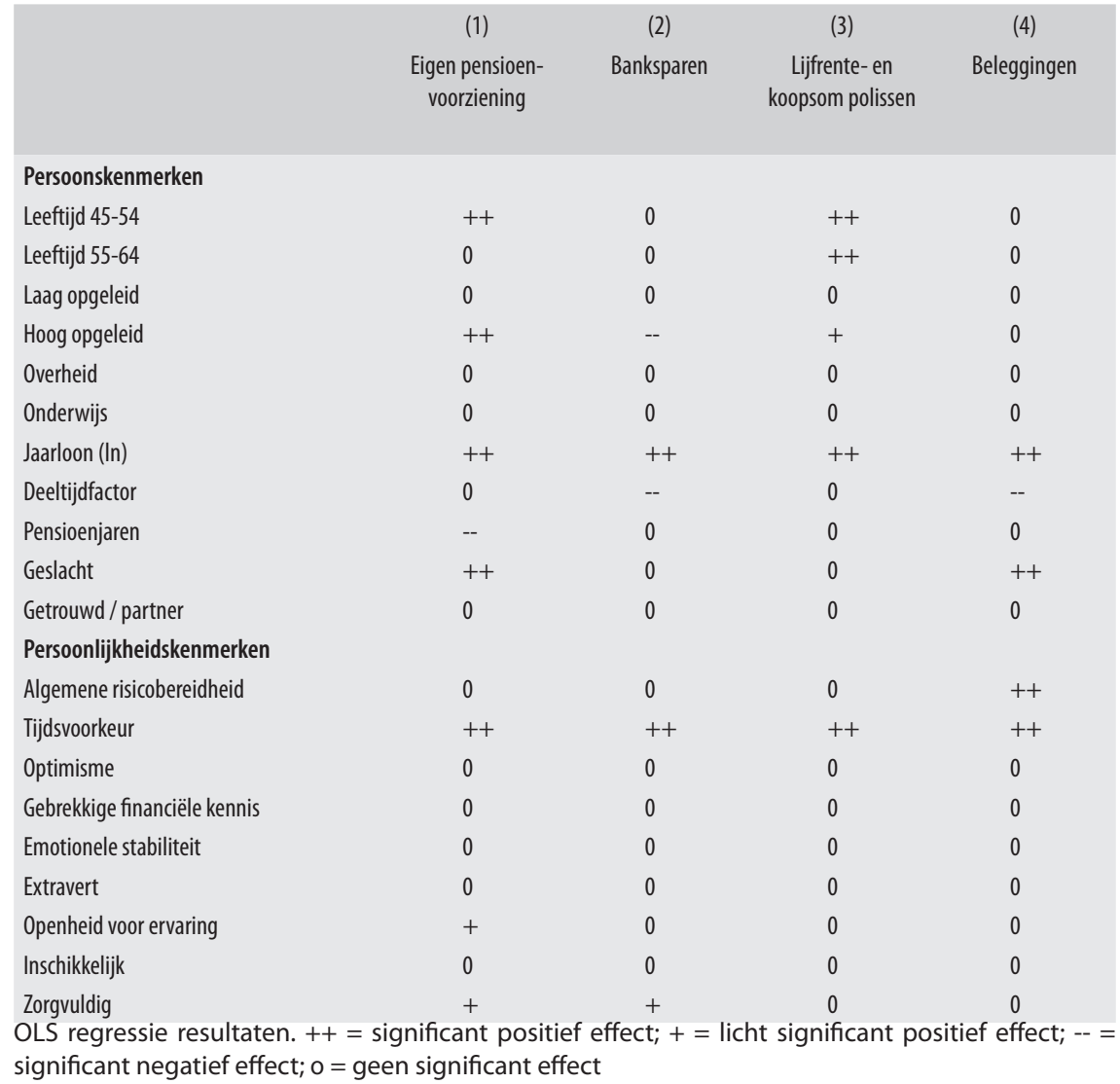


De persoonlijkheid van werknemers lijkt het bijsparen voor het pensioen minder te beïnvloeden. Alleen iemands tijdsvoorkeur draagt significant bij aan de kans om een eigen pensioenvoorziening te hebben. Mensen die de hoogste score hebben op de bereidheid om nu dingen op te geven om daarvan later profijt te hebben, hebben een $26 \%$ hogere kans om een eigen pensioenvoorziening te hebben dan degene die de laagste score heeft.

De andere persoonlijkheidskenmerken hebben echter wel een effect op de wijze waarop mensen investeren in hun pensioen. Voor de mensen die zelf sparen voor hun pensioen, blijkt dat zorgvuldige werknemers vaker kiezen voor banksparen, terwijl mensen die meer bereid zijn om risico's te lopen juist vaker kiezen om te beleggen. Wat betreft de persoonskenmerken valt verder op dat mannen vaker kiezen om te beleggen en dat parttimers minder vaak sparen bij een bank en eveneens minder vaak ervoor kiezen om te beleggen. Oudere werknemers en hoog opgeleiden maken juist wat vaker gebruik van lijfrente- en koopsompolissen.

\subsection{Persoonlijkheidskenmerken per sector}

In de voorgaande paragrafen hebben we laten zien dat persoonlijkheidskenmerken belangrijke determinanten zijn van individuele pensioenverwachtingen, iemands risicobereidheid en de mate waarin werknemers zelf sparen voor hun pensioen (de derde pijler van het pensioenstelsel). Zo is de pensioenleeftijd positief gecorreleerd met iemands tijdsvoorkeur, emotionele stabiliteit en de openheid voor nieuwe ervaringen, en negatief gecorreleerd met de risicobereidheid van werknemers. De risicobereidheid met betrekking tot de hoogte van het latere pensioen en de mate waarin werknemers beleggen voor hun pensioen worden significant positief beïnvloed door iemands algemene risicobereidheid en tijdsvoorkeur. Anderzijds nemen zorgvuldige mensen minder risico met hun pensioen en investeren zij zelf vaker in hun pensioen door middel van banksparen.

De Figuren 2.5 tot en met 2.13 laten zien welke type mensen er in de verschillende overheids- en onderwijssectoren werkzaam zijn. Deze inventarisatie geeft een indicatie voor het mogelijk gewenste maatwerk in de pensioencommunicatie met betrekking tot de verschillende sectoren. De figuren laten zien dat de risicobereidheid het grootst is bij degenen die werkzaam zijn als burgerpersoneel bij defensie of de provincies en waterschappen, terwijl de risicobereidheid relatief laag is in het primair onderwijs.

De bereidheid om nu dingen op te geven om daar in de toekomst profijt van te hebben varieert daarentegen weinig tussen de verschillende sectoren. Hetzelfde geldt voor optimisme en zorgvuldigheid. De financiële kennis van werknemers varieert daarentegen sterk tussen de verschillende sectoren. Maar $7 \%$ van de werknemers bij het wetenschappelijk onderwijs, onderzoek en wetenschapsbeleid en IO\% bij de academische ziekenhuizen heeft een gebrekkige financiële kennis. Bij de politie (I9\%), het 
primair onderwijs (I8\%) en de vrijwillige toetreders tot het ABP (I8\%) is dit percentage veel hoger.

Figuur 2.5

Persoonlijkheidskenmerken per sector: Risicobereidheid

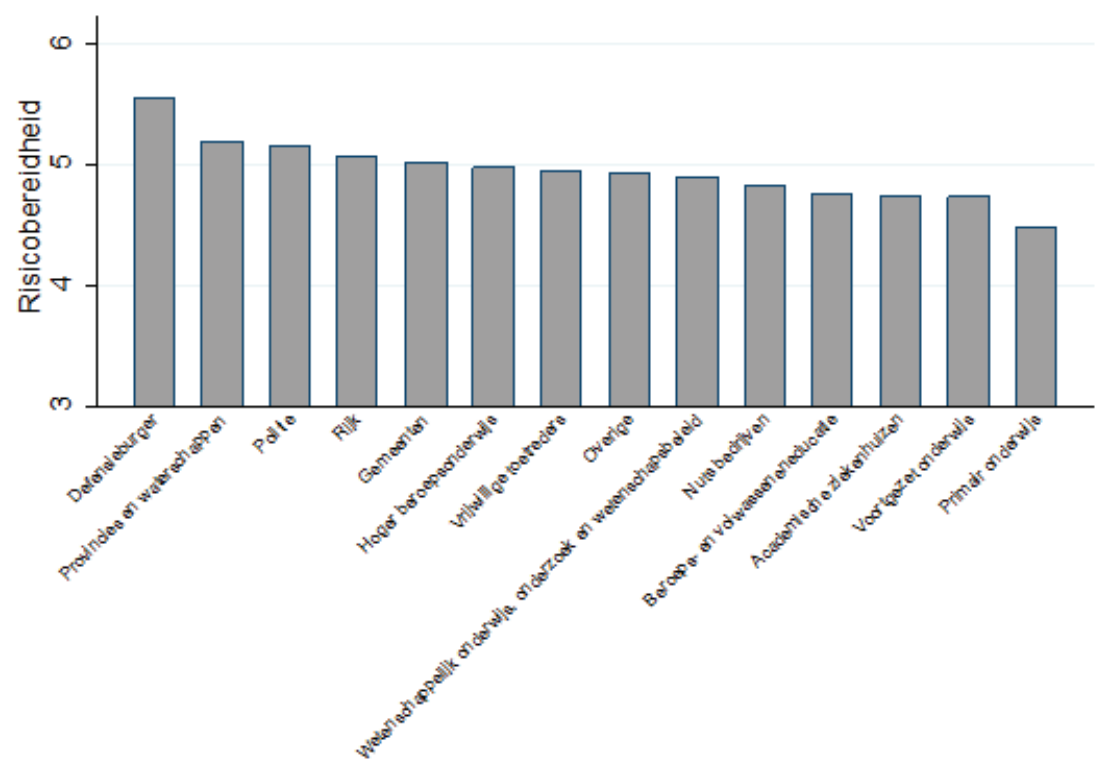

Figuur 2.6

Persoonlijkheidskenmerken per sector:Tijdsvoorkeur

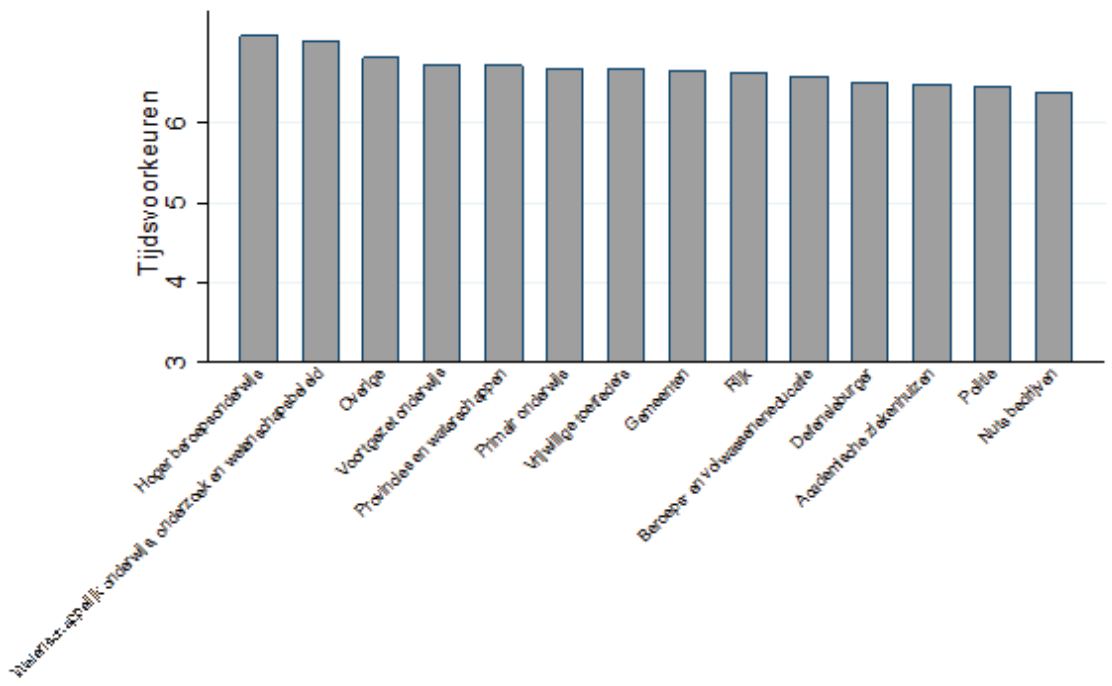


Figuur 2.7

Persoonlijkheidskenmerken per sector: Gebrekkige financiële kennis

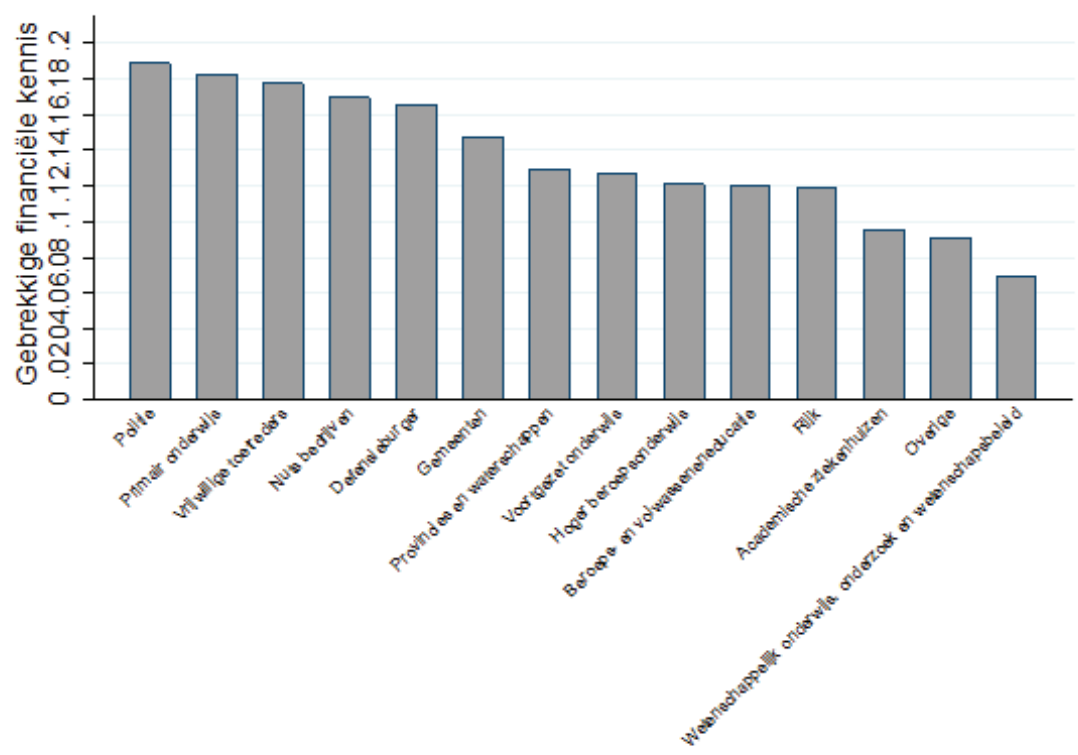

Figuur 2.8

Persoonlijkheidskenmerken per sector: Optimisme

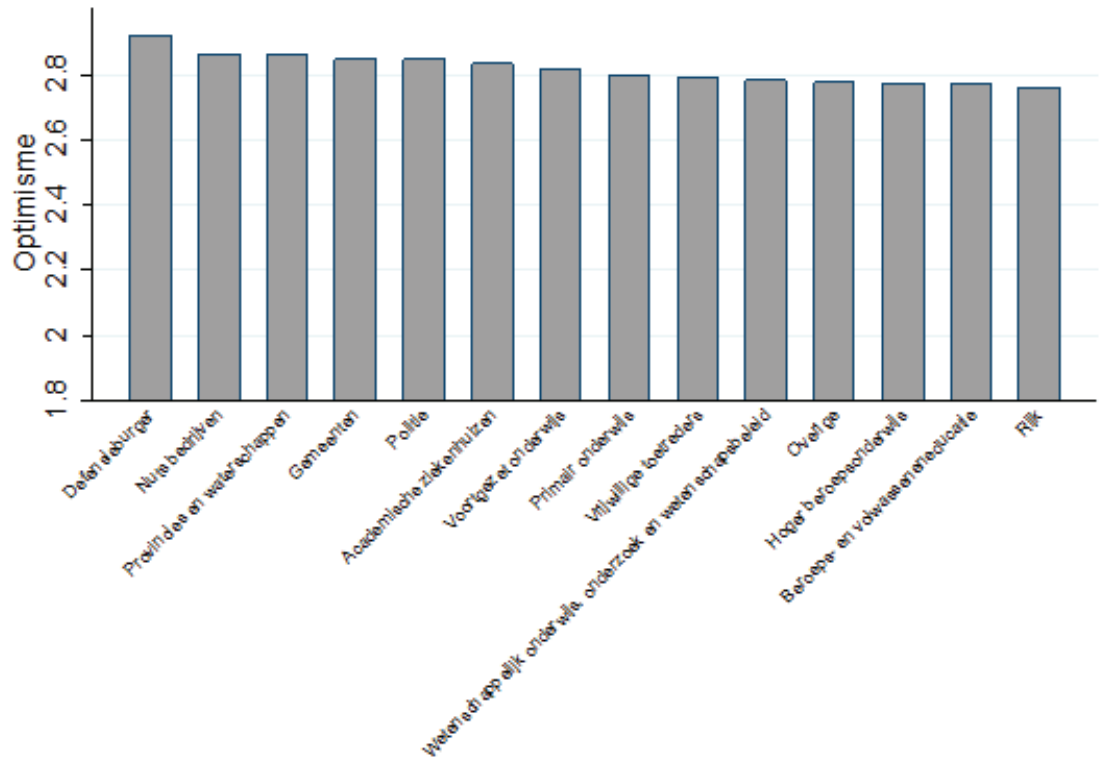


Figuur 2.9

Persoonlijkheidskenmerken per sector: Emotionele stabiliteit

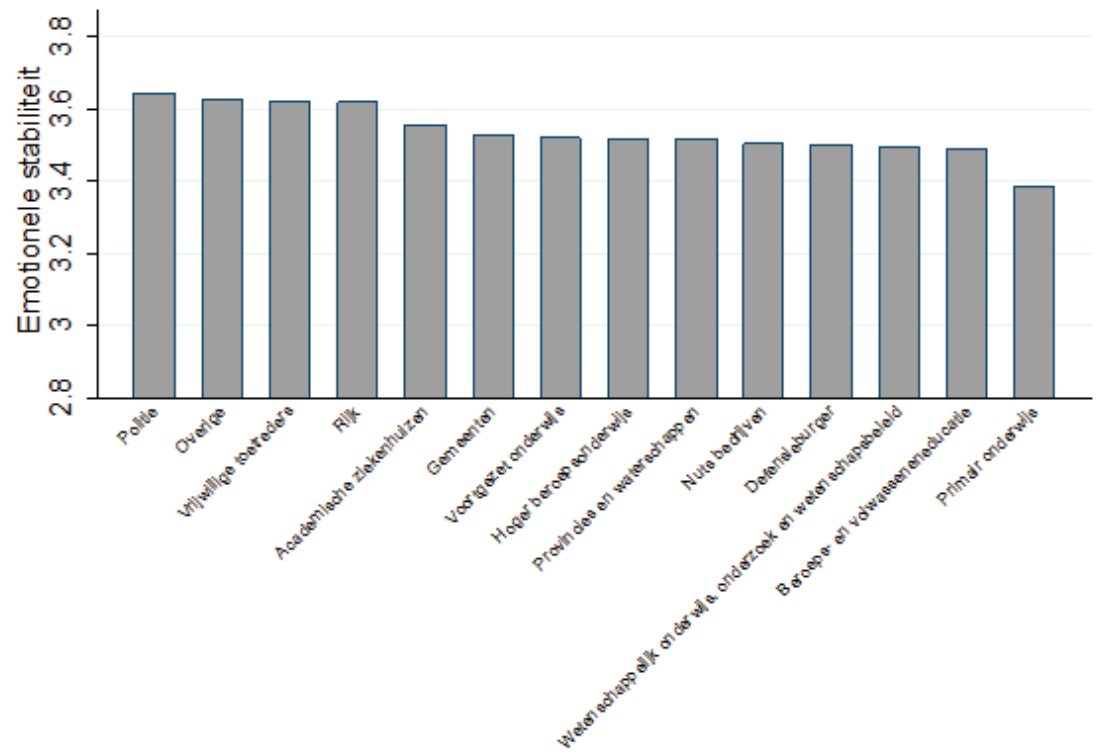

Figuur 2.10

Persoonlijkheidskenmerken per sector: Extravert

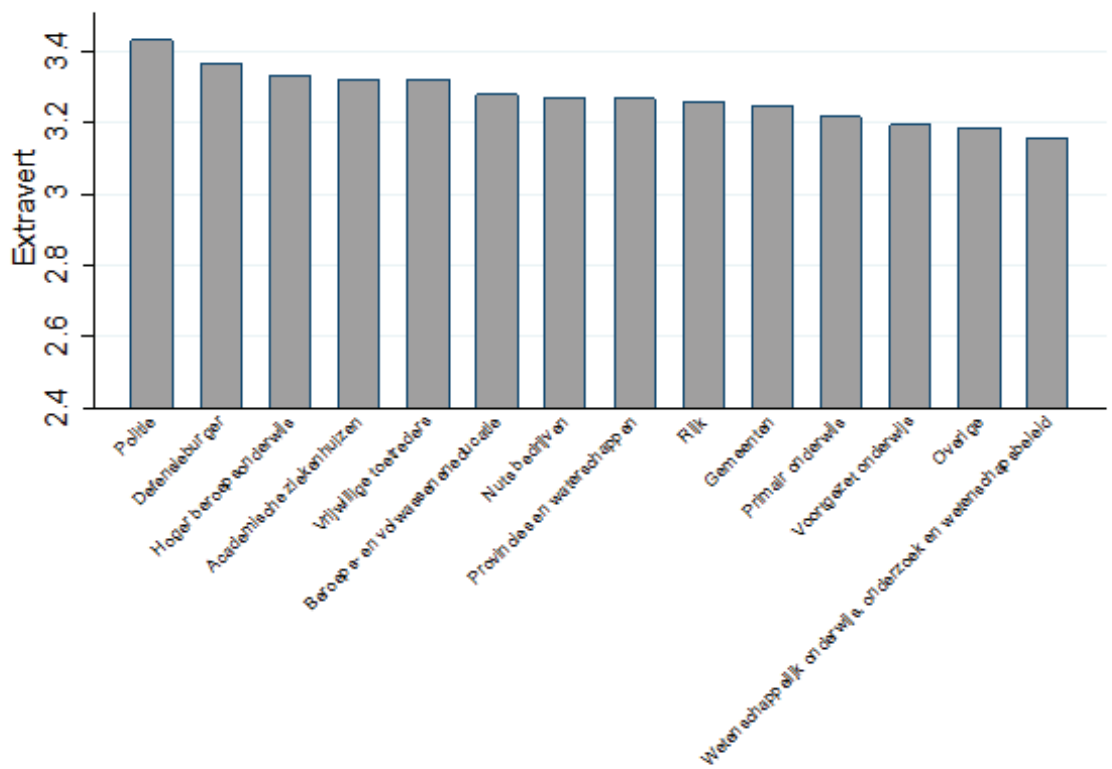


Figuur 2.11

Persoonlijkheidskenmerken per sector: Openheid voor ervaringen

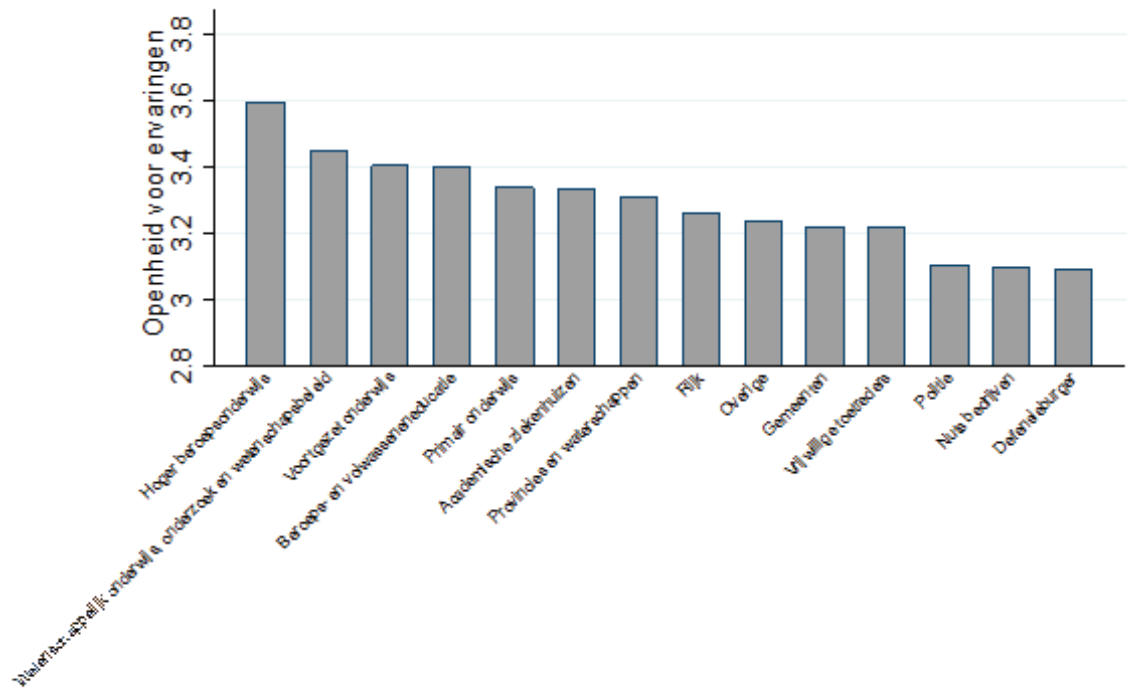

Figuur 2.12

Persoonlijkheidskenmerken per sector: Inschikkelijk

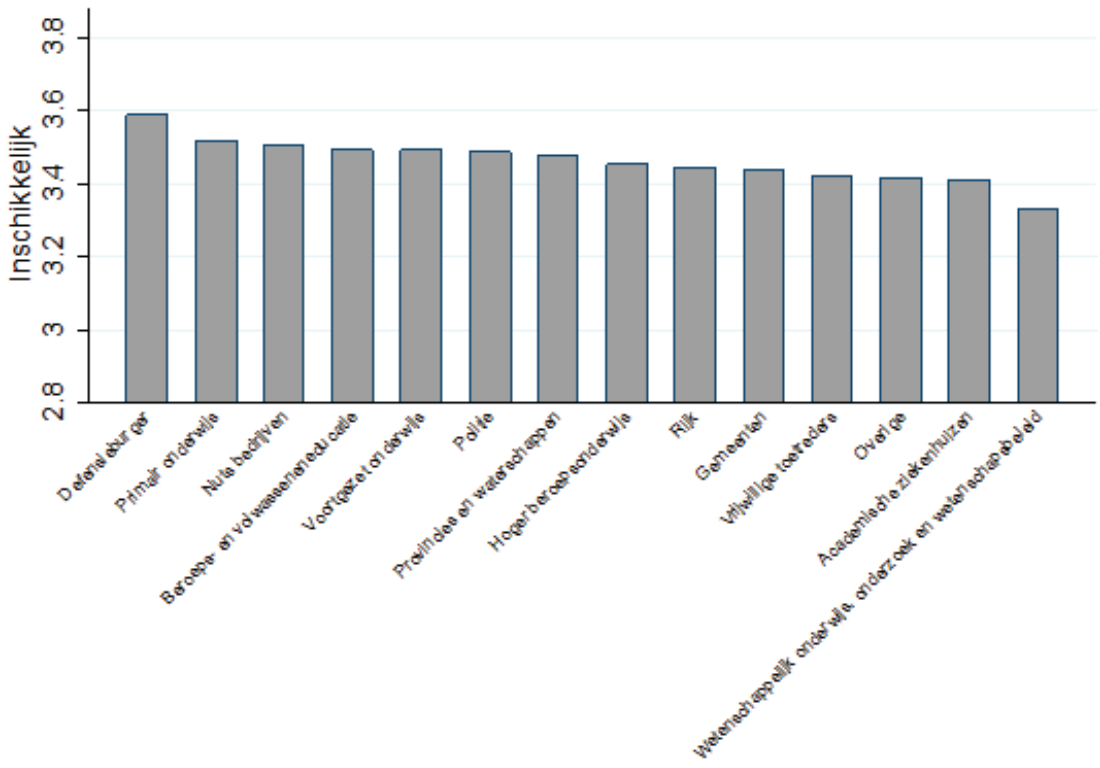


Figuur 2.13

Persoonlijkheidskenmerken per sector: Zorgvuldig

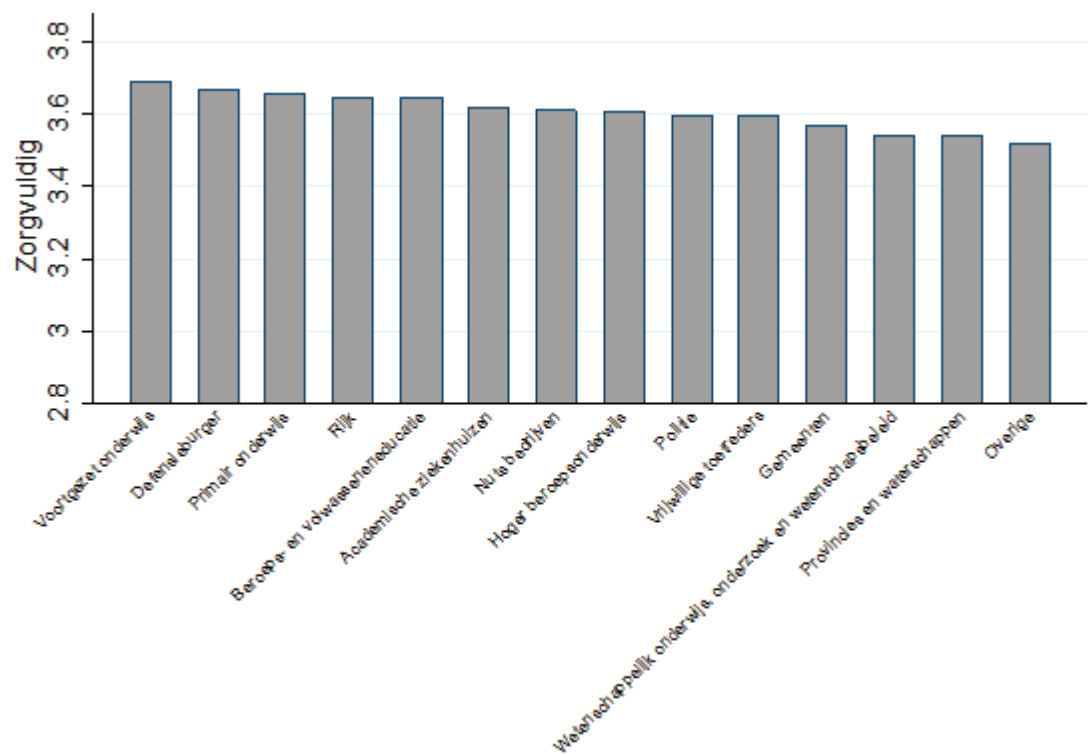

Wat betreft de overige Big Five persoonlijkheidskenmerken valt het op dat werknemers bij de politie en de vrijwillige toetreders meer emotioneel stabiel zijn, terwijl werknemers bij het beroeps- en volwassenenonderwijs en het primair onderwijs hierop relatief laag scoren. Werknemers bij de politie en defensie (burgerpersoneel) zijn vaker inschikkelijk en extravert, terwijl werknemers bij het wetenschappelijk onderwijs onderzoek en wetenschapsbeleid deze karaktertrekken juist minder sterk hebben ontwikkeld. Werknemers in het wetenschappelijk onderwijs, onderzoek en wetenschapsbeleid, en het hoger beroepsonderwijs staan echter meer open voor ervaringen, terwijl de werknemers bij de politie, defensie en de nutsbedrijven juist op deze karaktertrek lager scoren.

\subsection{Conclusie}

Uit de bovenstaande analyses op de werknemersenquête in de overheids- en onderwijssectoren kan een aantal conclusies worden getrokken:

- Persoonlijkheidskenmerken hebben een aanzienlijke invloed op de leeftijd waarop iemand met pensioen verwacht te gaan. Iemand die geen enkel risico wil nemen denkt 8 maanden later uit te treden dan iemand die zeer bereid is om risico's te nemen. Mensen die niet bereid is om van dingen af te zien om daar later voordeel van te hebben denken daarentegen 5 maanden eerder uit te treden dan degenen die zeer bereid is om dit te doen.

- De effecten van de Big Five persoonlijkheidskenmerken zijn eveneens sterk. Zo verwacht iemand die een zeer open karakter (score van vijf op de schaal) 
heeft ruim I2 maanden later met pensioen te gaan dan iemand die zeer gesloten is (score van één op de schaal), terwijl een hoge emotionele stabiliteit leidt tot een verhoging van de pensioenleeftijd met II maanden. Mensen die meer inschikkelijk zijn verwachten daarentegen bijna II maanden eerder met pensioen te gaan.

- Werknemers zijn minder bereid om risico's te nemen ten aanzien van hun pensioen. De risicobereidheid met betrekking tot de hoogte van het pensioen is met een score van 3,7 significant lager dan de gemiddelde algemene risicobereid van 4,9. Bijna één op de tien werknemers wil zelfs geen enkel risico nemen ten aanzien van hun pensioen.

- $\mathrm{Na}$ uitleg over de trade-off tussen risico en rendement veranderen bepaalde groepen werknemers echter van mening. Oudere werknemers, fulltimers en emotioneel meer stabiele werknemers zijn na de uitleg meer bereid om risico's te nemen ten aanzien van hun pensioen. Anderzijds zijn degenen die werkzaam zijn in het onderwijs na uitleg minder bereid om risico's te lopen.

- Door de uitleg over de trade-off tussen risico en rendement vindt er een opmerkelijke omslag plaats van het leeftijdspatroon in de bereidheid om risico te nemen met de hoogte van het eigen pensioen. Zonder uitleg willen oudere werknemers minder risico nemen ten aanzien van hun pensioen dan jongere werknemers. Na uitleg willen oudere werknemers juist meer risico nemen.

- De persoonlijkheid van werknemers lijkt minder bepalend te zijn voor het al dan niet bijsparen voor het eigen pensioen. Alleen iemands tijdsvoorkeur draagt significant bij aan de kans om een eigen pensioenvoorziening te hebben.

- De persoonlijkheidskenmerken hebben wel een effect op de wijze waarop mensen zelf investeren in hun latere pensioen. Zorgvuldige werknemers kiezen vaker voor banksparen, terwijl mensen die meer bereid zijn om risico's te lopen er juist vaker voor kiezen om te beleggen.

- Er zijn grote verschillen in de persoonlijkheidskenmerken van werknemers in de verschillende sectoren. De risicobereidheid is het grootst bij het defensie burgerpersoneel en de provincies en waterschappen en relatief laag in het primair onderwijs. Maar $7 \%$ van de werknemers in de sector wetenschappelijk onderwijs, onderzoek en wetenschapsbeleid en IO\% van de werkenden bij de academische ziekenhuizen heeft gebrekkige financiële kennis. Bij de politie ( $19 \%)$, het primair onderwijs ( $18 \%$ ) en de vrijwillige toetreders ( $18 \%)$ is dit percentage veel hoger. Bij de Big Five persoonlijkheidskenmerken valt het op dat werknemers bij de politie en de vrijwillige toetreders meer emotioneel stabiel zijn en werknemers bij de politie en defensie vaker inschikkelijk en extravert zijn, terwijl werknemers bij het wetenschappelijk onderwijs onderzoek en wetenschapsbeleid deze karaktertrekken juist minder sterk hebben ontwikkeld. Werknemers in het wetenschappelijk onderwijs, onderzoek en wetenschapsbeleid, en het hoger beroepsonderwijs staan daarentegen meer open voor ervaringen. 



\section{Vitaliteitsbeleid}

\subsection{Inleiding}

Het gezond en vitaal houden van alle medewerkers is van groot belang bij het productief optimaal inzetbaar houden van het personeel waarover een organisatie beschikt. Dit is temeer van belang tegen de achtergrond van de vergrijzende beroepsbevolking en het steeds verder naar achteren schuiven van de leeftijd waarop mensen met pensioen kunnen gaan. Werknemers kunnen zelf in belangrijke mate bijdragen aan hun vitaliteit door het nastreven van een gezonde levensstijl. Werkgevers kunnen daar echter ook een belangrijke bijdrage aan leveren door het voeren van een op de vitaliteit van medewerkers gericht HR-beleid en het inzetten van HR-tools die specifiek gericht zijn op het inzetbaar houden van oudere medewerkers.

In dit hoofdstuk gaan wij eerst in op het HR-beleid in het algemeen en het HR-beleid dat werkgevers voeren om hun medewerkers vitaal te houden. Daarna gaan wij in op het HR-beleid dat specifiek gericht is op de oudere medewerkers en het belang van het langer doorwerken. Ten slotte geven wij inzicht in de manier waarop werkgevers informatie over pensioenen doorgeven aan hun medewerkers.

\subsection{Op vitaliteit gericht HR-beleid}

De werkgeversenquête bevat veel vragen over het door de organisatie gevoerde HR-beleid. Dit is reeds eerder uitvoerig besproken in een eerder rapport (Fouarge et al. 20II). ${ }^{4}$ In de 2012 enquête gaat het om 49 vragen rond het gevoerd HR-beleid op het gebied van communicatie, scholing, loopbaan, gezondheid, flexibiliteit en arbeidsvoorwaarden. Hier beperken we ons tot zes aspecten van het HR-beleid:

I) onderzoek naar werkvermogen en vitaliteit;

2) periodiek preventief medisch onderzoek;

3) arbobeleid;

4. Fouarge, D., A. de Grip \& R. Montizaan (20II). Pensioenverwachtingen en personeelsbeleid. Verslag van de ROA enquête 20II. Maastricht: ROA-R-20II/9. 
4) lifestyleadvies;

5) leeftijdsbewust en levensfasebewust personeelsbeleid;

6) cursussen gericht op gezondheid en het vergroten van de belastbaarheid van werknemers.

Deze zes aspecten komen naar voren als dimensies van het HR-beleid dat zich het beste laat typeren als 'op vitaliteit gerichte HR-beleid'. ${ }^{6}$

Figuur 3.1

Op vitaliteit gericht HR-beleid in 2011 en 2012

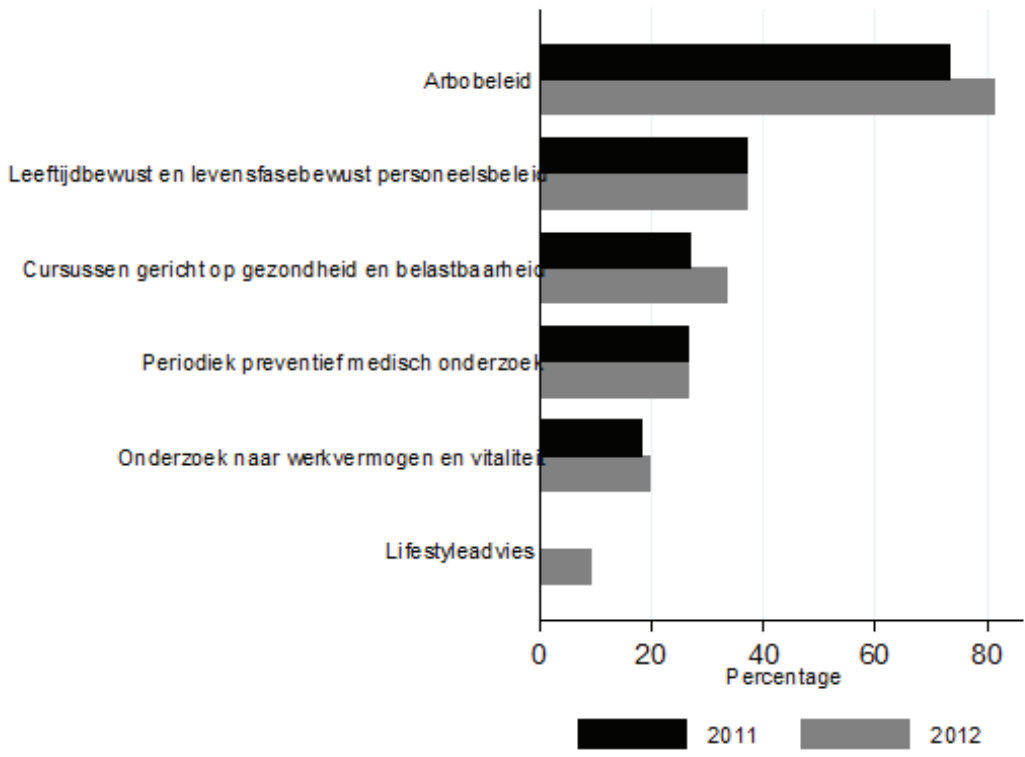

Voor elke aspect van het op vitaliteit gericht HR-beleid is aan werkgevers gevraagd om op een schaal van I tot 5 aan te geven of zij dit beleid voor geen enkele werknemer inzetten (I) of voor alle werknemers (5). Figuur 3.I geeft een overzicht van het percentage werkgevers dat het desbetreffende beleid voor nagenoeg alle werknemers inzet (score 4 of 5 ). De Figuur laat zien dat in 2012 ruim $80 \%$ van alle organisaties in de overheids- en onderwijssector een arbobeleid voeren. Dat is significant meer dan in 2011 , toen nog slechts $73 \%$ van de organisaties een arbobeleid voerde. ${ }^{7}$ De stijging doet zich vooral voor in de sectoren Onderwijs en Overig (Nutsbedrijven, Vrijwillige en overige toetreders). Daarnaast voert $37 \%$ van de bedrijven een leeftijdsbewust en levensfasebewust personeelsbeleid voor bijna alle medewerkers. Ongeveer een derde

5. Dit was niet opgenomen in de 20II vragenlijst. Life style advies kan echter een belangrijk instrument zijn om oudere werknemers te stimuleren om hun eigen lifestyle zodanig in te richten dat de eigen gezondheid (en daarmee hun productiviteit) waar mogelijk wordt bevorderd.

6. Naar aanleiding van een factoranalyse vallen deze aspecten van het HR-beleid samen in de eerste factor met een eigenvalue van 9,5. De items komen uit de HR gebieden scholing, gezondheid en arbeidsvoorwaarden en hebben allen een factorlading van 0,3 of meer.

7. De significantie is getoetst op $5 \%$. 
van de bedrijven biedt aan nagenoeg alle werknemers cursussen aan die gericht zijn op hun gezondheid en/of het vergroten van hun belastbaarheid. Periodiek preventief medisch onderzoek wordt door $26 \%$ van de werkgevers aan hun medewerkers aangeboden, terwijl er in $20 \%$ van de organisaties onderzoek naar het werkvermogen en de vitaliteit van het personeel plaatsvindt. Daarentegen geeft nog geen IO\% van de werkgevers hun medewerkers een lifestyleadvies.

In bijlage A wordt ingegaan op de sectorale verschillen in het voeren van een vitaliteitsbeleid. De verschillen tussen de sectoren zijn in het algemeen niet erg groot, behalve als het gaat om periodiek preventief medisch onderzoek dat significant minder gebruikt wordt in het onderwijs. Ook worden er in het onderwijs minder vaak lifestyle adviezen gegeven dan in de andere sectoren.

\subsection{HR-beleid rond duurzame inzetbaarheid van oudere werknemers}

Sommige HR-instrumenten zijn specifiek gericht op de inzetbaarheid van oudere medewerkers. Figuur 3.2 geeft een beeld van de ontwikkeling van het op duurzame inzetbaarheid gerichte HR-beleid van organisaties in de overheids- en onderwijssector tussen $201 \mathrm{I}$ en 20I2. Ook hier gaat het telkens om het percentage werkgevers dat het desbetreffende beleid voor nagenoeg alle werknemers inzet ( 4 of 5 op een antwoordschaal van I tot 5). De op de duurzame inzetbaarheid van oudere werknemers gerichte HR-instrumenten die het vaakst worden ingezet hebben betrekking op een ontziebeleid: leeftijdvakantiedagen en seniorenverlof. ${ }^{8}$ Beide HR-instrumenten komen in 2012 wel in minder organisaties voor dan in 20Ir. Alleen voor leeftijdvakantiedagen is deze afname significant.

Tussen $201 \mathrm{I}$ en 2012 is ook de inzet van de volgende op duurzame inzetbaarheid gerichte HR-instrumenten significant afgenomen: aanpassing van de werkplek, taakverlichting, extra opleiding of cursusdeelname, mentorfunctie voor oudere werknemers, promotie en extra storting voor het levensloopsparen. Daar staat tegenover dat het aantal bedrijven waar medewerkers na hun 65e mogen doorwerken significant is toegenomen. Tussen $201 \mathrm{I}$ en 2012 is ook het gebruik van deeltijdpensioen en salarisgaranties toegenomen, maar deze veranderingen zijn niet significant.

De op een duurzame inzetbaarheid van oudere medewerkers gerichte HR-instrumenten kunnen op basis van factoranalyse worden ingedeeld in vijf categorieën. Daarbij gaat het om maatregelen die gericht zijn op: I "taakaanpassing", 2 "beloningsprikkels", 3 "opleiden", 4 "arbeidsduurbeleid" en 5 "pensioenbeleid". Interessant is hierbij dat organisaties die hoog scoren op de component 'opleiden' niet meer werknemers op interne of externe cursussen of opleidingen sturen, maar wel een hoger budget aan opleidingen besteden. Bijlage B geeft een overzicht van de sectorverschillen in het

8. B. Lokhorst (20II). Duurzame inzetbaarheid en langer doorwerken in de CAO. 
gebruik van het op duurzame inzetbaarheid gerichte HR-beleid. Hieruit blijkt dat leeftijdvakantiedagen en deeltijdpensioen vooral ingezet worden bij de sector overheid, terwijl seniorenverlof vooral ingezet wordt in het onderwijs.

\section{Figuur 3.2}

Op duurzame inzetbaarheid van oudere medewerkers gericht HR-beleid, 2011 en 2012 (percentage bedrijven)

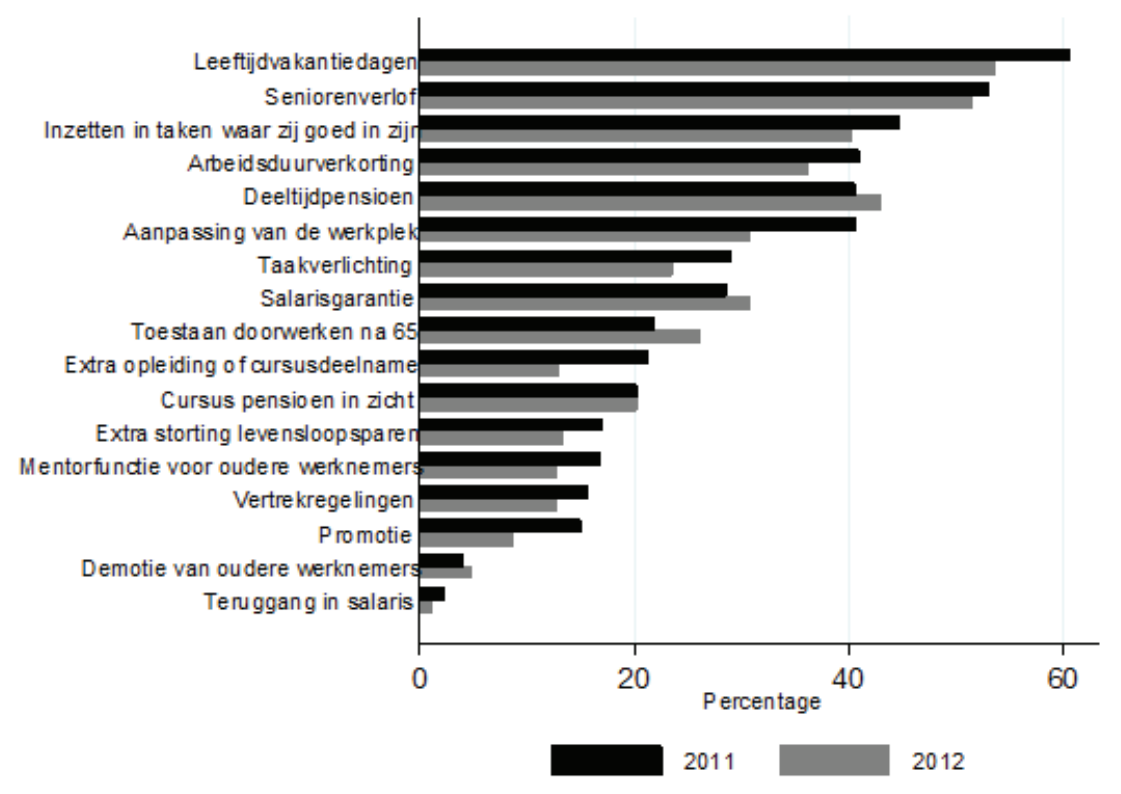

Figuur 3.3 laat het percentage werkgevers zien dat het eens is met enkele stellingen over het HR-beleid rond oudere werknemers. Het aanbieden van de mogelijkheid om in deeltijd te gaan werken komt het vaakst voor. Ook wordt vaak informatie gegeven over de financiële mogelijkheden om eerder uit te treden. Tussen 201 en 2012 zijn er over het algemeen geen grote veranderingen opgetreden. Wel blijkt dat in 2012 in alle sectoren significant vaker alternatieve mogelijkheden om eerder uit te treden worden aangeboden dan in 20II. Bovendien bieden organisaties in het onderwijs in 2012 oudere medewerkers significant vaker de mogelijkheid om in deeltijd te gaan werken dan in 201 . $^{9}$

9. Het is relevant om hierbij op te merken dat deeltijdwerken niet hetzelfde is als deeltijdpensioen. Bij deeltijdpensioen gaan mensen in deeltijd werken en voor de dagen dat zij niet werken ontvangen zij pensioen. 
Figuur 3.3

Stellingen rond inzet en beleid oudere werknemers, 2011 en 2012 (procenten)1)

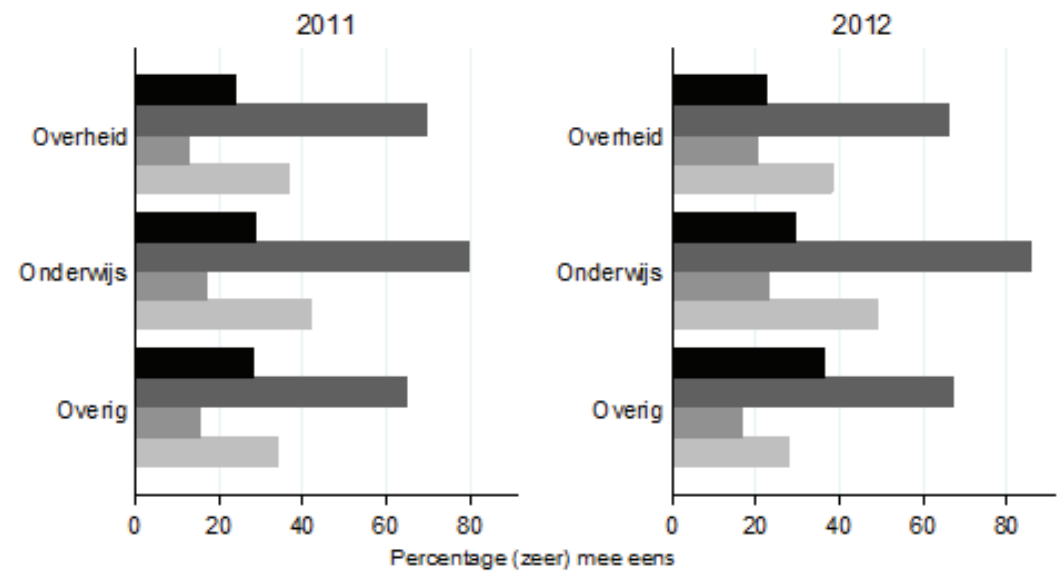

Organis atie heeft zich meer ingezet om werknemers tot hogere leeftijd asn werk te houden

Organis atie maskt het mogelijk dat oudere werknemers in deeltijd gasn werk en

Organis atie biedt alter natieve mogelijkheden om eerder vit te treden

Organisatie biedt informatie over financiele mogelijkheden om eerder vit te treden

1) Sector Overig heeft betrekking op Nuts bedrijven, Vrijwillige toetreders en Overige bedrijven

Figuur 3.4

Belang voor de personele bezetting dat werknemers langer doorwerken, 2011 en 2012 (procenten) ${ }^{1)}$

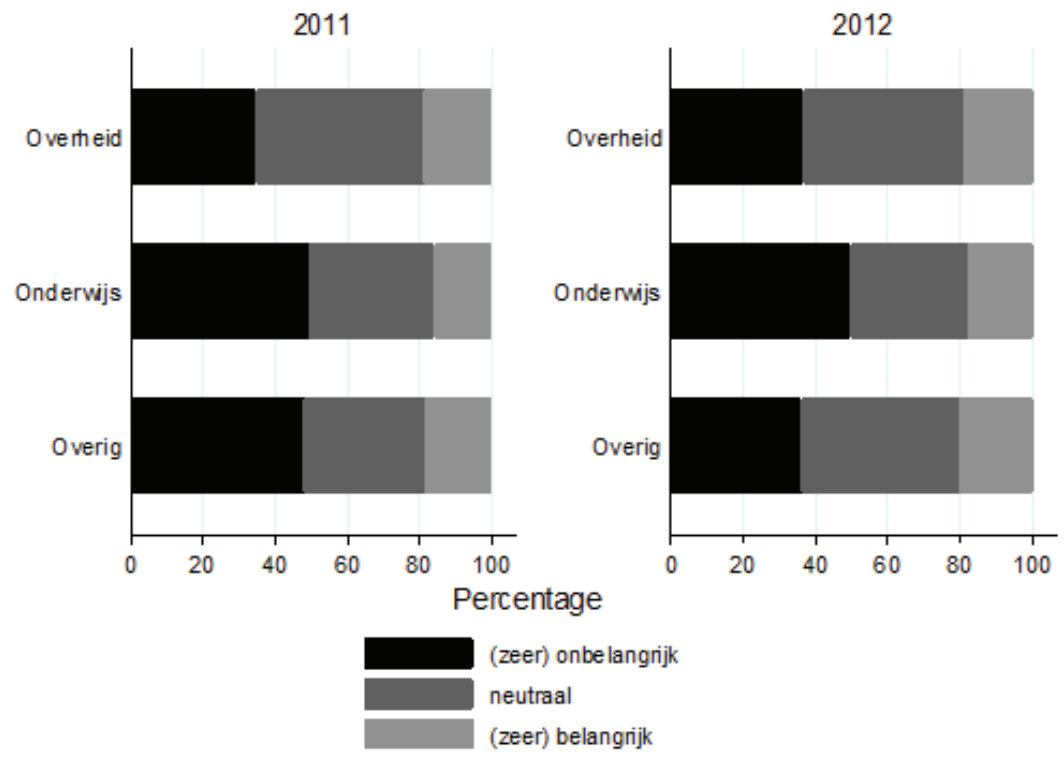

1) Sector Overig heeft betrekking op Nuts bedrijven, Vrijwillige toetreders en Overige bedrijven 
Ons vorige rapport liet zien dat slechts een fractie van de werkgevers het voor de organisatie belangrijk vindt dat hun medewerkers langer doorwerken. ${ }^{\text {Io }}$ Ondanks de verdere vergrijzing van de beroepsbevolking en de beleidsmaatregelen die genomen zijn om ouderen langer aan het werk te houden is het besef van het belang van langer doorwerken bij de organisaties in de overheids- en onderwijssector vrijwel niet toegenomen en nog steeds zeer gering (Zie Figuur 3.4). ${ }^{\text {II }}$ In 20 II vond $17,4 \%$ van de organisaties het belangrijk dat medewerkers langer doorwerken. In 2012 is dat percentage met I \%-punt gestegen naar I8,5\%. Wel is in de sector 'overig' het percentage bedrijven dat aangeeft dat het onbelangrijk is voor de organisatie dat ouderen langer doorwerken gedaald van $48 \%$ in 20 II naar $36 \%$ in 2012 .

We hebben onderzocht of er een relatie bestaat tussen het HR-beleid dat gericht is op de inzetbaarheid van oudere medewerkers (Figuur 3.2) en het belang dat werkgevers toekennen dat werknemers langer doorwerken (Figuur 3.4). Daarbij maken we gebruik van de vijf eerder gedefinieerde categorieën van HR-instrumenten (maatregelen die gericht zijn op: I "taakaanpassing", 2 "beloningsprikkels", 3 "opleiden", 4 "arbeidsduurbeleid" en 5 "pensioenbeleid"). Uit deze extra analyse blijkt allereerst dat organisaties die het belangrijk vinden dat hun personeel langer doorwerkt zich ook meer inzetten om hun medewerkers tot een hogere leeftijd aan werk te houden. Ook blijkt dat organisaties die het langer doorwerken belangrijk vinden hun personeel vaker opleiden en een 'pensioenbeleid' voeren dat gericht is op het toestaan van langer doorwerken na 65 jaar. Bovendien doen de werkgevers die het belangrijk vinden voor de organisatie dat oudere medewerkers langer blijven werken meer aan de vitaliteit van hun medewerkers. Daarentegen voeren deze organisaties minder vaak een 'arbeidsduurbeleid' dat gericht is op arbeidsduurverkorting of deeltijdpensioen. Er is echter geen verband tussen het belang dat werkgevers hechten aan het langer doorwerken en het voeren van een 'inzetbaarheidbeleid' gericht op taakaanpassing en beloningsprikkels.

Overigens blijkt ook dat bij organisaties die het belangrijk vinden dat hun medewerkers langer doorwerken de financiële situatie van de organisatie beter is.

Io. Fouarge, D., A. De Grip, A. Mohamed and R. Montizaan (20I2). Pensioenverwachtingen en personeelsbeleid. Jaarverslag 20I2. Maastricht: ROA-R-20I2/4.

II. In het onderwijs speelt niet alleen de vergrijzing van het lerarenbestand een rol, maar ook het afnemend leerlingenaantal. Het kan zijn dat werkgevers in het onderwijs zich goed bewust zijn van het laatste proces, en daarom verwachten op termijn hun oudere arbeidskrachten minder hard nodig te hebben. Daar staat tegenover dat leerlingen zich op een steeds hoger niveau scholen en dat deelname aan post-initieel leren steeds toeneemt (Borghans, L., D. Fouarge \& A. de Grip (20II). Een leven lang leren in Nederland. Maastricht: ROA-R-20II/5) waardoor er een zekere vraag naar leraren blijft bestaan. 


\subsection{Informatie over pensioenen}

Aan de werkgevers in de overheids- en onderwijssector is gevraagd langs welke weg zij hun medewerkers beter proberen te informeren over hun pensioen. Daarbij konden zij vijf adviesbronnen aangeven:

- account managers ABP;

- doorverwijzing naar de klantsupport ABP;

- organisatie workshop door ABP;

- presentatie door ABP;

- onafhankelijke financiële adviseurs.

Van alle organisaties heeft $34 \%$ geen enkele van deze adviesbronnen ingezet om hun medewerkers beter te informeren over hun pensioen, terwijl $4 \%$ van de organisaties alle vijf adviesbronnen heeft ingezet. Het percentage organisaties dat geen van de bronnen heeft ingezet om hun medewerkers te informeren is het hoogst in het onderwijs (37\%) en de sector overig (38\%). Bij de overheid was dit bij $27 \%$ van de organisaties het geval.

Zoals Figuur 3.5 laat zien zijn de meest gebruikte adviesbronnen de accountmanagers en het klantsupport van ABP. Ruim 63\% van de overheidsorganisaties heeft deze adviesbronnen ingezet. In het onderwijs is het gebruik van deze adviesbronnen Io $\%$-punten lager. Het inzetten van onafhankelijke financiële adviseurs is in alle drie sectoren de minst voorkomende bron van advies om werknemers beter te informeren over hun pensioen. 


\section{Figuur 3.5}

In 2012 ingezette adviesbronnen om werknemers beter te informeren over hun pensioen (procenten)
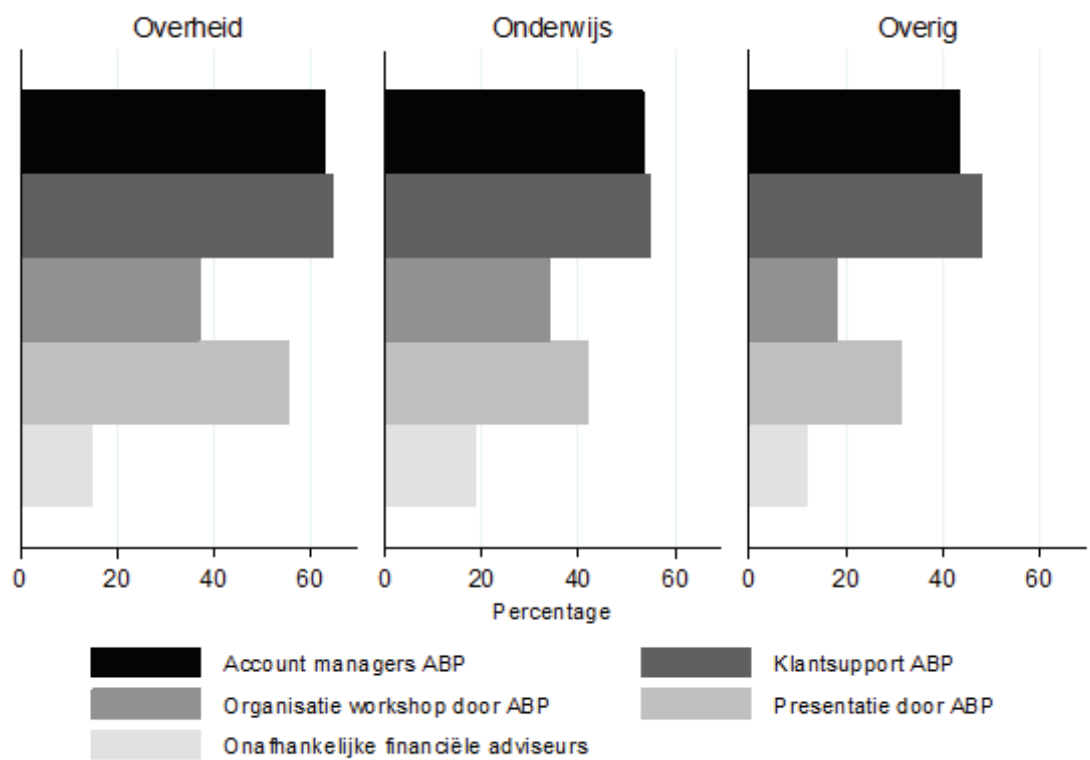

Account managers ABP

Organisatie workshop door ABP

Klantsupport ABP

Presentatie door ABP

Ona fhankelijke financiële adviseurs

1) Sector Overig heeft betrekking op Nuts bedrijven, Vrijwillige toetreders en Overige bedrijven

Figuur 3.6 geeft een overzicht van het percentage organisaties dat hun medewerkers in 2012 voorlichting heeft gegeven over de veranderingen op het gebied van pensioenen. De figuur laat zien dat zowel in de sector overheid als in het onderwijs $46 \%$ van de organisaties hun medewerkers voorlichting heeft gegeven over de veranderingen in pensioenen tegenover $38 \%$ van de organisaties in de sector overig. Van de organisatie die voorlichting hebben gegeven heeft $40 \%$ dit gedaan tijdens één op één gesprekken met medewerkers, 32\% tijdens algemene bijeenkomsten en $22 \%$ tijdens bijeenkomsten voor specifieke groepen medewerkers. $34 \%$ van de werkgevers geeft aan op andere wijze voorlichting te hebben gegeven. 


\section{Figuur 3.6}

Percentage organisaties dat in 2012 de medewerkers voorlichting heeft gegeven over de veranderingen in het pensioenstelsel ${ }^{1)}$

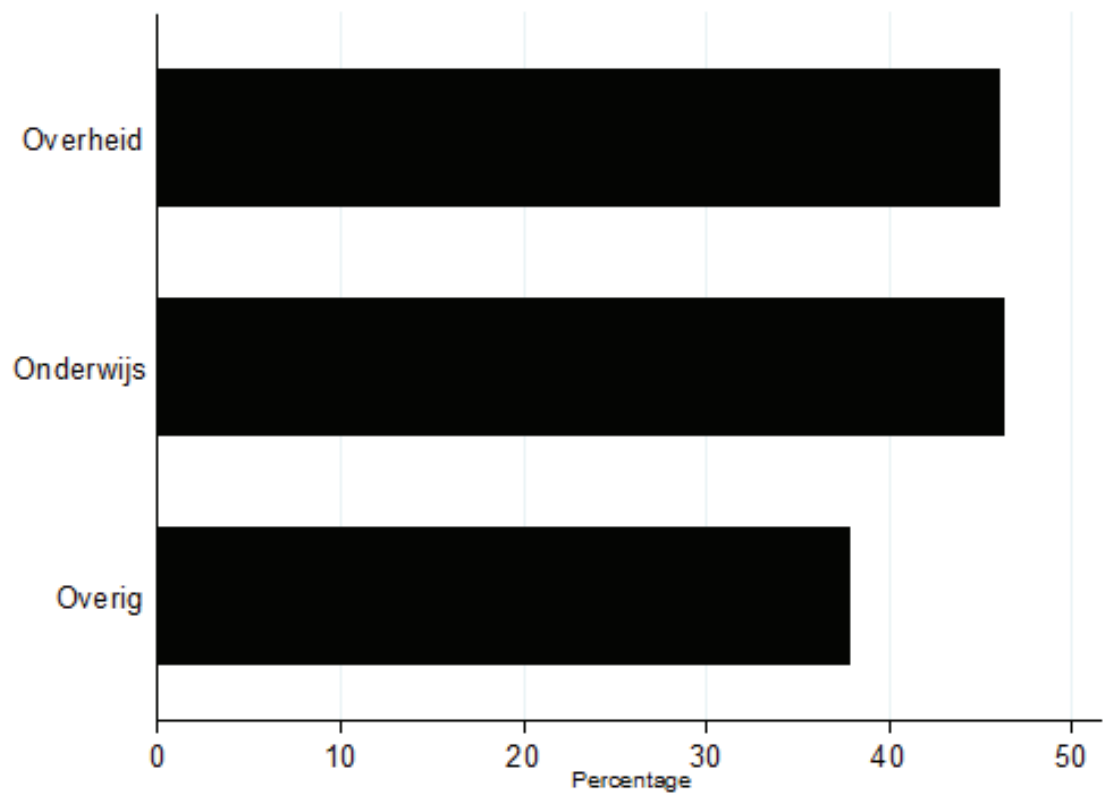

1) Sector Overig heeft betrekking op Nuts bedrijven, Vrijwillige toetreders en Overige bedrijven

\subsection{Conclusie}

Uit analyses op basis van de werkgeversenquête in de overheids- en onderwijssector kan worden geconcludeerd dat:

- Een groot deel van het HR-beleid gericht op het verbeteren van de duurzame inzetbaarheid van oudere medewerkers kan worden gekenmerkt als een vitaliteitsbeleid. Het gaat daarbij om onderzoek naar het werkvermogen en de vitaliteit van medewerkers, periodiek preventief medisch onderzoek, arbobeleid, lifestyleadvies, leeftijdsbewust en levensfasebewust personeelsbeleid en cursussen gericht op de gezondheid en het vergroten van de belastbaarheid van werknemers.

- Tussen $201 \mathrm{I}$ en 2012 is het arbobeleid en het geven van cursussen gericht op gezondheid en vergroting van de belastbaarheid van medewerkers significant toegenomen. Arbobeleid is het daarbij het meest gevoerde beleid op het gebied van vitaliteit.

- Nog geen IO\% van de werkgevers geeft in het kader van een vitaliteitsbeleid de eigen medewerkers lifestyleadviezen. 
- Van de HR-instrumenten die specifiek gericht zijn op de duurzame inzetbaarheid van met name oudere medewerkers is het gebruik van leeftijdvakantiedagen, de aanpassing van de werkplek, taakverlichting, extra opleiding of cursusdeelname, mentorfuncties voor oudere werknemers, promotie en extra storting levensloopsparen tussen $201 \mathrm{I}$ en $20 \mathrm{I} 2$ significant afgenomen. Daarentegen is het toestaan van doorwerken na 65 jaar significant toegenomen.

- Ondanks de verdere vergrijzing van de beroepsbevolking en de beleidsmaatregelen die genomen zijn om ouderen langer aan het werk te houden is er bij de werkgevers in de overheids- en onderwijssector weinig veranderd in het besef van het belang van langer doorwerken. In 2012 vond I8,5\% van de organisaties het belangrijk voor de organisatie dat hun medewerkers langer doorwerken. Dat is maar I \%-punt meer dan in $201 \mathrm{~s}$.

- Organisaties die het belangrijk vinden dat hun medewerkers langer doorwerken voeren vaker een vitaliteits- en opleidingsbeleid, staan vaker toe dat werknemers na 65 jaar kunnen doorwerken, en stimuleren minder vaak arbeidsduurverkorting en deeltijdpensionering.

- $46 \%$ van de organisaties in de sector overheid en de onderwijssector hebben hun medewerkers in 2012 voorlichting gegeven over de veranderingen in de pensioenen. In de sector overig lag dit percentage nog lager: $38 \%$. Van de organisatie die voorlichting hebben gegeven heeft $40 \%$ dit gedaan tijdens één op één gesprekken met medewerkers, 32\% tijdens algemene bijeenkomsten en $22 \%$ tijdens bijeenkomsten voor specifieke groepen medewerkers. 


\section{Werknemersgedrag en HR-beleid}

\subsection{Inleiding}

Door de voortdurende hervormingen van het pensioenstelsel zullen werknemers zich moeten instellen op een verlenging van hun loopbaan met enkele jaren. Werkgevers zullen zich echter eveneens moeten beraden op de vraag hoe zij uiteenlopende groepen werknemers gemotiveerd, gezond en productief tot op hogere leeftijd aan het werk kunnen houden dan wel op een bepaald moment in de loopbaan naar ander werk toe kunnen leiden. Een belangrijke vraag hierbij is welke HR-instrumenten gericht op duurzame inzetbaarheid het meest effectief zijn om langer doorwerken te stimuleren. Om een antwoord te kunnen geven op deze vraag hebben we het HR-beleid van organisaties dat gericht is op duurzame inzetbaarheid (uit de werkgeversenquête) gerelateerd aan de verwachte pensioenleeftijd van hun eigen medewerkers (uit de werknemersenquête). De uitkomsten van deze analyse laten zien dat uitsluitend het voeren van een opleidingsbeleid significant bijdraagt aan het verhogen van de verwachte pensioenleeftijd. Onze analyses tonen echter ook aan dat maar weinig werkgevers bereid zijn om oudere medewerkers een opleiding aan te bieden.

\subsection{Verwachte pensioenleeftijd en HR-beleid van werkgevers}

In hoofdstuk 3 zijn op basis van de werkgeversenquête vijf HR-instrumenten die gericht zijn op duurzame inzetbaarheid geïdentificeerd. Het gaat om maatregelen die gericht zijn op:

I) taakaanpassing;

2) beloningsprikkels;

3) opleiden;

4) arbeidsduurbeleid;

5) pensioenbeleid.

In tabel 4.I is de inzet van deze vijf HR-instrumenten in een organisatie gerelateerd aan de verwachte pensioenleeftijd van de eigen medewerkers. Het blijkt dat het opleiden 
van medewerkers tot een significant hogere pensioenleeftijd leidt. Een toename van de intensiteit van het opleidingsbeleid met één standaarddeviatie verhoogt de verwachte pensioenleeftijd met ongeveer I, 5 maand. De andere HR-instrumenten hebben geen significant effect. Het is daarbij vooral opvallend dat het pensioenbeleid (o.a. het toestaan om door te werken na 65 jaar en vertrekregelingen) geen effect heeft op de pensioenverwachtingen van werknemers. Een mogelijke reden hiervoor is dat werknemers geen goed inzicht hebben in het pensioenbeleid dat hun eigen werkgever biedt. Mogelijk omdat werkgevers gedurende de financiële crisis weinig nadruk leggen op de mogelijkheden om langer door te werken.

\section{Tabel 4.1}

Relatie tussen HR-beleid en de verwachte pensioneringsleeftijd

$\begin{array}{lc}\text { Taakaanpassing } & 0 \\ \text { Beloningsprikkels } & 0 \\ \text { Opleiden } & ++ \\ \text { Arbeidsduurbeleid } & 0 \\ \text { Pensioenbeleid } & 0 \\ \text { OLS regressie resultaten. }++=\text { significant positief effect; -- = significant negatief effect; en o = geen } \\ \text { significant effect. }\end{array}$

Het voeren van een op opleiden gericht HR-beleid lijkt vooral een effect te hebben op de intensiteit van cursusdeelname, maar niet op het aantal medewerkers dat een cursus volgt (zie ook hoofdstuk 3). Tabel 4.2 laat zien dat organisaties die meer aandacht besteden aan opleiden niet meer werknemers een cursus laten volgen of hen langere cursussen aanbieden. Daarentegen volgen de medewerkers van deze organisatie die worden getraind wel meer cursussen en trainingen. Bovendien blijkt dat hun werkgever vaker het initiatief neemt om een cursus te volgen. Eén standaarddeviatie toename in de score van het opleidingsbeleid verhoogt de kans om gestimuleerd te worden om een cursus te volgen met ongeveer $4 \%$

Tabel 4.2

Cursusdeelname en HR-beleid

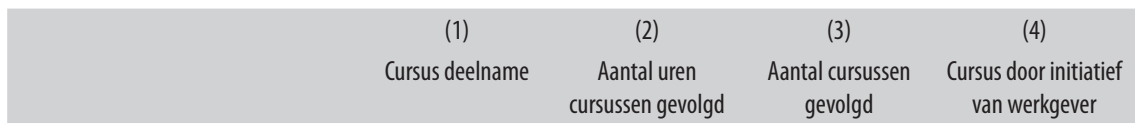

\begin{tabular}{lcccc} 
Taakaanpassing & 0 & 0 & 0 & 0 \\
Beloningsprikkels & 0 & 0 & ++ & 0 \\
Opleiden & 0 & 0 & ++ & ++ \\
Arbeidsduurbeleid & 0 & 0 & 0 & -- \\
$\begin{array}{l}\text { Pensioenbeleid } \\
\text { OLS regressie resultaten }+++= \\
\text { significant effect. }\end{array}$ & 0 & 0 & 0 & 0 \\
\hline
\end{tabular}




\subsection{Kans op training naar leeftijd}

Het opleidingsbeleid is dus een belangrijk instrument dat werknemers kan stimuleren om langer door te werken. ${ }^{\mathrm{I} 2}$ De vraag is vervolgens in welke mate werkgevers ook bereid zijn om oudere medewerkers cursussen en of trainingen aan te bieden. We hebben geprobeerd een antwoord te vinden op deze vraag door een 'vignetstudie' onder de werkgevers (meestal gaat het hierbij om de HR-directeur) uit te zetten. Daarbij wordt hen gevraagd zich voor te stellen dat hun organisatie een budget vrijmakkt voor het volgen van trainingen en cursussen op HBO-niveau (dit is het modale opleidingsniveau bij de overheid en het onderwijs). Vervolgens wordt hen een aantal keren gevraagd aan wie van twee (fictieve) medewerkers zij de cursus zouden willen aanbieden. De twee werknemers verschillen daarbij van elkaar qua geslacht, leeftijd, opleidingsniveau, relevante ervaringsjaren en de match tussen vakopleiding en functie.

De uitkomsten van de keuzes zijn weergegeven in Figuur 4.I, waarbij ingezoomd wordt op de dimensie van de leeftijd van de werknemer. ${ }^{13}$ Daar er telkens een keuze moet worden gemaakt tussen twee medewerkers kunnen de kansen op training niet in absolute termen worden uitgedrukt, maar relatief ten opzichte van andere leeftijdsgroepen. Daarom zijn de kansen in de figuur genormeerd op de jongste leeftijdsgroep, waardoor duidelijk te zien is hoe de kans op scholing toe- of afneemt met het oplopen van de leeftijd van de werknemers.

Figuur 4.I laat zien dat de kans op training in het onderwijs voor alle leeftijdsgroepen boven de 35 jaar significant lager is dan voor medewerkers in de leeftijd van 26-35 jaar. In het onderwijs is de kans dat een oudere werknemer een cursus aangeboden krijgt ruim $20 \%$-punt lager dan voor een jongere medewerker. De figuur laat bovendien zien dat de kans op training in alle drie sectoren sterk daalt nadat medewerkers 55 jaar zijn geworden. Oftewel, werkgevers zijn duidelijk minder bereid om oudere werknemers een training aan te bieden.

I2. Anderzijds laat een studie van Montizaan et al. (20II) zien dat pensioenversoberingen ook de trainingsparticipatie op latere leeftijd stimuleert.

I3. Het gaat in Figuur 4.I om de voorspelde marginale effecten uit een probit model (kenmerken vignet vastgepind op voltijd werknemers op HBO niveau met Io jaar ervaring) met controle voor sector, geslacht, leeftijd, opleiding en dienstjaren van de personeelsfunctionaris. 


\section{Figuur 4.1}

Kans om gekozen te worden voor training, naar leeftijd en sector, 2012'1)

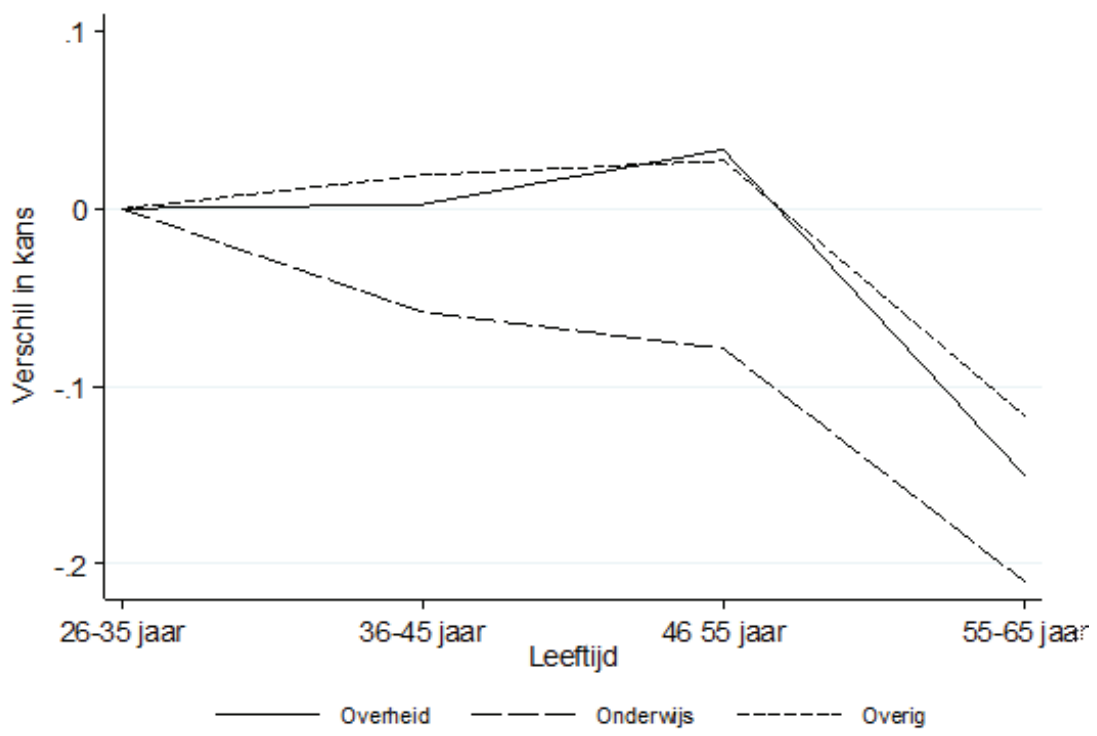

1) Sector Overig heeft betrekking op Nuts bedrijven, Vrijwillige toetreders en Overige bedrijven

In de vignetstudie wordt ook een onderscheid gemaakt naar het soort cursus of training. Daarbij worden vier soorten cursussen onderscheiden: een cursus gericht op (I) het aansturen van mensen, (2) het gebruik maken van verbale en communicatieve vaardigheden, (3) onderzoeken of (4) ontwikkelen of verzamelen en verwerken van informatie. In Figuur 4.2 wordt voor elke soort cursus aangegeven hoeveel de kans dat iemand de cursus door de werkgever krijgt aangeboden met het oplopen van de leeftijd verandert. De Figuur laat zien dat oudere medewerkers een lagere kans op training hebben, ongeacht het soort training. De kans om een training aangeboden te krijgen om mensen aan te sturen daalt vanaf ongeveer 45 jaar, terwijl de kans om een cursus te volgen die het gebruik van verbale en communicatieve vaardigheden en het onderzoeken of ontwikkelen stimuleert pas afneemt vanaf 55 jaar. Bij cursussen die gericht zijn op het verzamelen en verwerken van informatie neemt de kans steeds verder af met het oplopen van de leeftijd. Ook hier is de terugval het grootst bij de 55-plussers. 
Figuur 4.2

Kans om gekozen te worden voor training, naar leeftijd en soort cursus, 2012

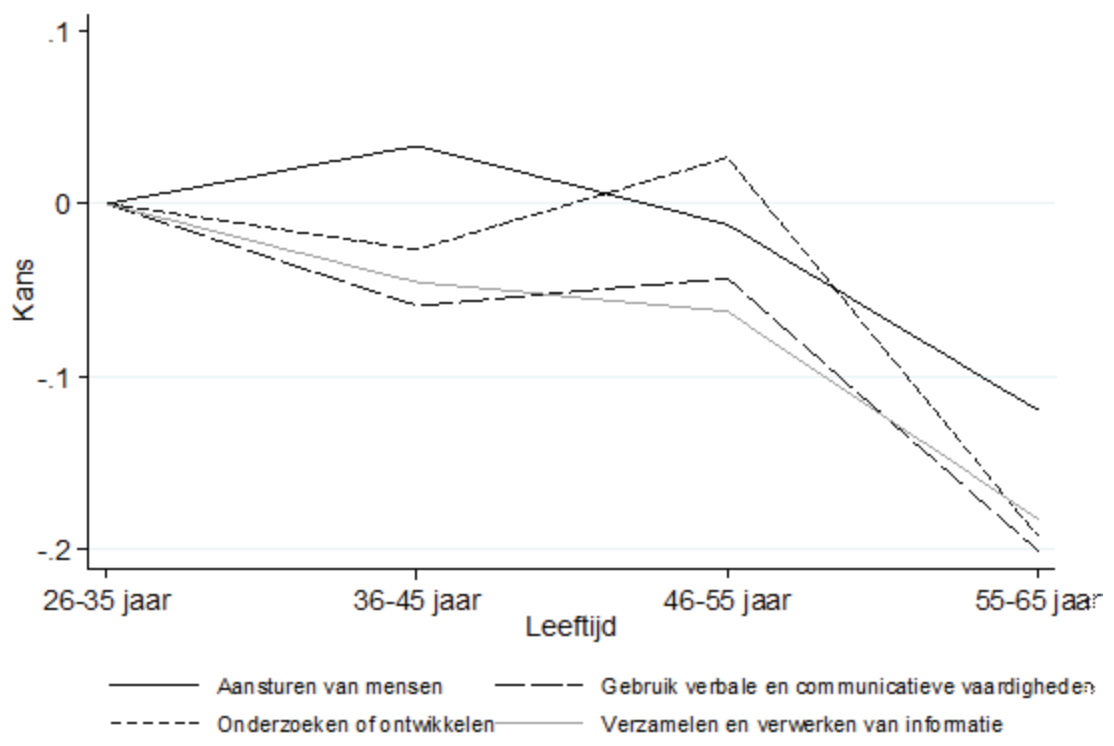

\subsection{Conclusie}

De belangrijkste conclusies die uit dit hoofdstuk kunnen worden getrokken zijn:

- Van alle HR-instrumenten die gericht zijn op het verbeteren van de duurzame inzetbaarheid van oudere medewerkers en zijn opgenomen in onze analyses draagt uitsluitend het opleidingsbeleid significant bij aan het verhogen van de verwachte pensioenleeftijd.

- Een intensiever opleidingsbeleid leidt er niet toe dat meer werknemers een opleiding gaan volgen. Wel neemt het aantal gevolgde trainingen toe alsook het percentage medewerkers dat aangeeft dat hun werkgever het initiatief heeft genomen om een cursus te volgen.

- Uit onze analyses blijkt echter duidelijk dat zowel in de overheids- als onderwijssector werkgevers weinig bereid zijn om oudere medewerkers een opleiding aan te bieden, ongeacht het soort opleiding. Dit geldt vooral voor de 55-plussers die in de organisatie werkzaam zijn. 



\section{Conclusies}

In deze rapportage is verslag gedaan van de belangrijkste uitkomsten van het onderzoek 'Duurzame inzetbaarheid en pensionering' dat is uitgevoerd in de verschillende sectoren die zijn aangesloten bij het Pensioenfonds ABP. Ons onderzoek heeft zich gericht op de vraag wat de versoberingen in het pensioenstelsel en het bevorderen van duurzame inzetbaarheid van werknemers en werkgevers vergen? Deze onderzoeksvraag speelt in op de informatiebehoefte over hoe uiteenlopende groepen werknemers gemotiveerd, gezond en productief langer kunnen blijven doorwerken. Door de versoberingen van de tweede pijler van het pensioenstelsel en het langzamerhand steeds verder naar achteren schuiven van de AOW-gerechtigde leeftijd zullen werknemers moeten wennen aan het idee dat zij een aantal jaren langer moeten werken. Doordat medewerkers later met pensioen gaan zal de gemiddelde leeftijd van het personeelsbestand in vrijwel alle organisaties nog sneller stijgen dan verwacht zou mogen worden op basis van de demografische ontwikkelingen. Hierdoor zal de duurzame inzetbaarheid van medewerkers een steeds belangrijkere plaats moeten krijgen op de HR-agenda. Werkgevers zullen zich daarom moeten beraden op de wijze waarop zij gaan inspelen op de in de komende jaren steeds groter wordende groep oudere medewerkers in hun organisatie.

Voor het beantwoorden van de bovenstaande onderzoeksvragen hebben wij gebruik gemakkt van twee datasets. De eerste dataset bestaat uit een combinatie van administratieve data en survey data die zijn gebaseerd op twee enquêtes die in 201 en 2012 zijn gehouden onder een representatieve steekproef van werknemers in de leeftijd van 35 tot 65 jaar die werkzaam zijn in de sectoren die ABP bedient. De tweede dataset is gebaseerd op een werkgeversenquête die een gedetailleerd beeld geeft van de HR instrumenten die werkgevers in $201 \mathrm{I}$ en 2012 hebben ingezet om oudere werknemers langer met plezier inzetbaar te houden.

\subsection{Pensioenverwachtingen}

De analyses op de werknemersenquête in de overheids- en onderwijssector zijn gericht op de rol die persoonlijkheidskenmerken hebben voor de vorming van iemands pensioenverwachtingen. Deze informatie is uitermate relevant omdat het bijdraagt tot een betere kennis over hoe werknemers hun verwachtingspatroon ten aanzien van hun pensioneringsleeftijd en de hoogte van hun pensioen vormen en eventueel zelf 
gaan bijsparen om een hoger pensioen te kunnen krijgen of om alsnog vervroegd uit te treden. Op basis hiervan kunnen werkgevers en pensioenfondsen meer maatwerk leveren in de pensioencommunicatie. Dit laatste wordt steeds urgenter doordat werknemers in de afgelopen jaren voortdurend geconfronteerd worden met veranderingen in hun pensioenrechten en toenemende keuzemogelijkheden binnen het pensioenstelsel. Uit de analyses blijkt duidelijk dat de verwachte pensioenleeftijd in de periode $20 \mathrm{II}-2 \mathrm{OI} 2$ fors is gestegen en dat persoonlijkheidskenmerken een sterke invloed hebben op de verwachte pensioenleeftijd:

- Een hogere algemene risicobereidheid leidt tot een daling in de verwachte pensioenleeftijd, terwijl een hogere algemene bereidheid om van dingen af te zien om daar later voordeel van te hebben tot een stijging van de verwachte pensioenleeftijd leidt. De effecten van de Big Five persoonlijkheidskenmerken op de verwachte pensioenleeftijd zijn eveneens substantieel. Zo verwachten mensen die emotioneel stabieler zijn en degenen die meer open staan voor nieuwe ervaringen later met pensioen te gaan, terwijl mensen die meer inschikkelijk zijn juist verwachten dat ze eerder met pensioen gaan.

- Verder blijkt dat werknemers weinig bereid zijn om risico's te nemen met betrekking tot de hoogte van hun pensioen. Bijna één op de tien werknemers wil op dit punt zelfs geen enkel risico nemen. Echter, de risicobereidheid is gevoelig voor uitleg die men krijgt over de wisselwerking tussen risico en rendement. Daarbij is het interessant dat het leeftijdspatroon in de bereidheid om risico te nemen met betrekking tot de hoogte van het eigen pensioen zelfs omdraait door de uitleg over de wisselwerking tussen risico en rendement. Zonder uitleg willen oudere werknemers minder risico nemen voor hun pensioen dan jongere werknemers. Na uitleg willen oudere werknemers juist meer risico nemen.

- De persoonlijkheid van werknemers blijkt minder invloed te hebben op het bijsparen in derde pijler van het pensioensysteem. Alleen iemands tijdsvoorkeur draagt significant bij aan de kans om een eigen pensioenvoorziening te hebben. Persoonlijkheidskenmerken hebben echter wel invloed op de wijze waarop mensen investeren in hun pensioen. Zorgvuldige werknemers kiezen vaker voor banksparen, terwijl mensen die meer bereid zijn om risico's te lopen juist vaker kiezen om te beleggen.

- Het blijkt overigens dat de persoonlijkheidskenmerken van werknemers sterk verschillen tussen de verschillende sectoren. Zo is de risicobereidheid het grootst bij het defensie burgerpersoneel en de provincies en waterschappen en is deze relatief laag is in het primair onderwijs. Daarnaast heeft maar $7 \%$ van de werknemers in de sector wetenschappelijk onderwijs, onderzoek en wetenschapsbeleid en IO\% van de werkenden bij de academische ziekenhuizen gebrekkige financiële kennis, terwijl dit percentage veel hoger is bij de politie (I $\%$ ), het primair onderwijs ( $18 \%$ ) en de vrijwillige toetreders (I8\%). Dit impliceert dat maatwerk in de pensioencommunicatie per sector noodzakelijk is. 


\subsection{Vitaliteitsbeleid}

In hoofdstuk 3 is ingegaan op het HR-beleid dat werkgevers voeren om hun medewerkers vitaal te houden en het HR-beleid dat specifiek gericht is op de oudere werknemers. Het gezond en vitaal houden van de medewerkers is van groot belang om hen voldoende productief inzetbaar te houden. Vitaliteitsbeleid is daarbij niet alleen gericht op ouderen, maar ook op jongeren. Werkgevers kunnen daarnaast echter ook HR-instrumenten inzetten die specifiek gericht zijn op het inzetbaar houden van oudere arbeidskrachten. De analyses laten een gemengd beeld zien van het HR-beleid:

- Enerzijds kan een groot deel van het HR-beleid worden gekenmerkt als een beleid dat gericht is op vitaliteit van de werknemers. Het gaat daarbij om onderzoek naar het werkvermogen en vitaliteit, periodiek preventief medisch onderzoek, arbobeleid, lifestyleadvies, leeftijdsbewust en levensfasebewust personeelsbeleid en het aanbieden van cursussen gericht op iemands gezondheid en het vergroten van de belastbaarheid van medewerkers.

- Tussen 201 en 2012 is het aantal organisaties dat een arbobeleid voert en hun medewerkers cursussen aanbiedt die gericht zijn op gezondheid en vergroting van de belastbaarheid significant toegenomen. De stijging in het gebruik van arbobeleid doet zich vooral voor in de sectoren onderwijs en overig (nutsbedrijven, vrijwillige en overige toetreders).

- Ook blijkt dat organisaties die het van belang achten dat hun medewerkers langer doorwerken vaker gebruik maken van HR-instrumenten gericht op het stimuleren van vitaliteit, opleidingen en langer doorwerken.

- Anderzijds blijkt dat in 2012 de aspecten van het HR-beleid die specifiek gericht zijn op de duurzame inzetbaarheid van met name oudere werknemers, het gebruik van leeftijdvakantiedagen, aanpassing van de werkplek, taakverlichting, extra opleiding of cursusdeelname, mentorfunctie voor oudere werknemers, promotie en extra storting levensloopsparen significant minder vaak worden toegepast dan in $201 \mathrm{I}$.

- Ook is er ondanks de toenemende vergrijzing van de beroepsbevolking en het overheidsbeleid waardoor ouderen langer moeten doorwerken, weinig veranderd in het belang dat werkgevers hechten aan het langer doorwerken van hun medewerkers. In 2012 vond maar $18,5 \%$ van alle organisaties in de overheids- en onderwijssector het voor hun organisatie belangrijk dat medewerkers langer doorwerken.

- Opvallend is ook dat een minderheid van alle organisaties hun medewerkers in 2012 voorlichting hebben gegeven over de veranderingen in de pensioenen: In de overheidsector en in het onderwijs heeft $46 \%$ van de organisaties dit gedaan, tegenover slechts $38 \%$ van de organisaties in de sector overig. 


\subsection{Werknemersgedrag en HR-beleid}

In hoofdstuk 4 is ten slotte onderzocht welke HR-instrumenten die gericht zijn op de duurzame inzetbaarheid van medewerkers het meest effectief zijn om het langer doorwerken te stimuleren. Uit deze analyse blijkt dat het HR-beleid dat organisaties voeren er inderdaad toe kan bijdragen / faciliteren dat medewerkers later met pensioen denken te gaan. Dit geldt met name voor het opleidingsbeleid:

- $\mathrm{Bij}$ organisaties die een beter opleidingsbeleid voeren verwachten de medewerkers significant later met pensioen te gaan.

- Een intensiever opleidingsbeleid leidt er niet toe dat meer werknemers een training gaan volgen. Wel volgen de medewerkers van deze organisaties die reeds trainen meer trainingen dan de medewerkers van organisaties die minder aandacht besteden aan hun opleidingsbeleid. Bovendien geven de medewerkers van deze organisaties vaker aan dat hun werkgever het initiatief heeft genomen om een bepaalde cursus of training te volgen.

- Werkgevers in de overheids- en onderwijssector zijn in het algemeen weinig bereid om oudere medewerkers een opleiding aan te bieden, ongeacht het soort opleiding. Het stimuleren van werkgevers om in het menselijk kapitaal van hun oudere medewerkers te blijven investeren kan een belangrijke bijdragen leveren aan een verdere verhoging van de arbeidsparticipatie van 55-plussers.

\subsection{Beleidsaanbevelingen}

Op basis van resultaten uit deze rapportage kunnen de volgende beleidsaanbevelingen worden geformuleerd voor het communicatiebeleid rondom pensioneren:

- Pensioenverwachtingen variëren sterk met persoonlijkheidskenmerken van individuele werknemers. Om de communicatie over pensionering richting werknemers te optimaliseren is het daarom van groot belang om een beter beeld te krijgen over hoe verschillende mensen over hun pensioen denken, en om te bepalen welke mensen denken langer te zullen doorwerken, in welke mate zij bereid zijn om risico te nemen ten aanzien van de hoogte van hun pensioen, en hoeveel zij zelf voor hun pensioen bijsparen. Deze rapportage laat zien dat het mogelijk is om door middel van enkele korte vragen een snelle inventarisatie van de persoonlijkheid van werknemers te maken. Vervolgens kunnen pensioenfondsen en werkgevers deze informatie gebruiken om hun communicatie aan te passen aan individuele behoeften of kunnen zij proberen het verwachtingspatroon van werknemers te corrigeren.

- Zonder uitleg over de mogelijke negatieve consequenties van een automatische zekerheidsreflex voor de gemiddelde pensioenhoogte zijn werknemers risicoaverser. Sociale partners en pensioenfondsen moeten derhalve een heldere uitleg geven van deze afruil zodat werknemers uiteindelijk optimale keuzes kunnen maken. 
- Er zijn grote verschillen in de persoonlijkheidskenmerken tussen de verschillende sectoren. Sociale partners en pensioenfondsen moeten bij hun communicatie specifiek rekening houden met een significant lager niveau van financiële kennis bij de politie, het primair onderwijs, en vrijwillige toetreders.

De analyses ten aanzien van inventarisatie van het door de werkgevers gevoerde vitaliteitsbeleid en de rol van HR-beleid voor de individuele pensioenverwachtingen leveren vervolgens drie concrete beleidsaanbevelingen op:

- Er zijn maar weinig werkgevers die lifestyle adviezen geven aan hun werknemers. Dit terwijl van lifestyle adviezen een belangrijke preventieve werking kunnen uitgaan op o.a. de gezondheid en de duurzame inzetbaarheid van werknemers. Er bestaat derhalve nog ruimte om werknemers te informeren en te adviseren over de consequenties van een verkeerde lifestyle op hun duurzame inzetbaarheid.

- Sociale partners moeten werkgevers blijven informeren over het belang dat hun werknemers doorwerken. Duidelijk blijkt dat werkgevers maar weinig besef hiervan hebben.

- De verwachte pensioenleeftijd wordt, zoals de resultaten laten zien, het meest gestimuleerd door het voeren van een intensief opleidingsbeleid. Werkgevers zijn anderzijds weinig bereid om oudere werknemers een training aan te bieden. Het voorlichten en stimuleren van werkgevers om ook oudere werknemers te gaan trainen is derhalve noodzakelijk voor een verdere verhoging van de arbeidsparticipatie van ouderen. 



\section{Verwijzingen}

Borghans, L., D. Fouarge \& de Grip A. (20II). Een leven lang leren in Nederland. Maastricht: ROA-R-2OII/5.

Chetty, R. (2006), A New Method of Estimating Risk Aversion, American Economic Review, Vol 95, I82I-I834.

De Grip A. Lindeboom, M., \& Montizaan R. 20I2. "Shattered Dreams: The Effects of Changing the Pension System Late in the Game," Economic Journal, Royal Economic Society, vol. I22(559), pp I-25, 03.

Fouarge, D., A. de Grip \& R. Montizaan (20II). Pensioenverwachtingen en personeelsbeleid. Verslag van de ROA enquête 20II. Maastricht: ROA-R-20II/9

Fouarge, D., A. De Grip, A. Mohamed and R. Montizaan (2012). Pensioenverwachtingen en personeelsbeleid. Jaarverslag 20I2. Maastricht: ROA-R-20I2/4.

Furnham, A., McManus, I. C., \& Scott, D. (2003). Personality, empathy and attitudes to animal welfare. Anthrozoös, I6, I35-I46.

Lokhorst B. (20II). Duurzame inzetbaarheid en langer doorwerken in de CAO.

Lusardi \& O. Mitchell (2007). 'Financial Literacy and Retirement Preparedness. Evidence and Implications for Financial Education,' Business Economics, pp 35-44.

Lusardi \& O. Mitchell (2008). 'Planning and Financial Literacy: How Do Women Fare?,' American Economic Review, Vol. 98(2), pp 413-I7.

McManus, I. C. \& Furnham, A. (2006). Aesthetic activities and aesthetic attitudes: Influences of education, background and personality on interest and involvement in the arts. British Journal of Psychology, 97, 555-587.

Montizaan, R. \& Cörvers, F. \& De Grip, A. (2010). "The effects of pension rights and retirement age on training participation: Evidence from a natural experiment," Labour Economics, Elsevier, vol. I7(I), pp. 240-247.

Montizaan, R.M., Vendrik, M.C.M. "Misery Loves Company Exogenous Shocks in Retirement Expectations and Social Comparison Effects on Subjective Well-Being", Journal of Economic Behavior and Organization (2013), http://dx.doi.org/IO.IOI6/j.jebo.2013.I0.009

Van Rooij, M., Lusardi, A. \& Alessie R. (20II). 'Financial literacy and stock market participation', Journal of Financial Economics, Vol. IOI,(2), pp 449-472.

Scheier, M. F., Carver, C. S., \& Bridges, M. W. (1994). Distinguishing optimism from neuroticism (and trait anxiety, self-mastery, and self-esteem): A re-evaluation of the Life Orientation Test. Journal of Personality and Social Psychology, 67, 1063-1078. 



\section{Bijlage A: Op vitaliteit gericht HR-beleid, percentage organisaties naar sector}

\begin{tabular}{|c|c|c|c|c|c|c|}
\hline & \multicolumn{3}{|c|}{2011} & \multicolumn{3}{|c|}{2012} \\
\hline & $\begin{array}{l}\text { Overheid } \\
\quad \%\end{array}$ & $\begin{array}{c}\text { Onderwijs } \\
\%\end{array}$ & $\begin{array}{l}\text { Overig } \\
\%\end{array}$ & $\begin{array}{c}\text { Overheid } \\
\%\end{array}$ & $\begin{array}{c}\text { Onderwijs } \\
\%\end{array}$ & $\begin{array}{c}\text { Overig } \\
\%\end{array}$ \\
\hline Cursussen gericht op gezondheid en belastbaarheid & 34 & 20 & 27 & 36 & 32 & 32 \\
\hline Periodiek preventief medisch onderzoek & 36 & 14 & 38 & 35 & 16 & 40 \\
\hline Onderzoek naar werkvermogen en vitaliteit & 18 & 15 & 28 & 18 & 20 & 21 \\
\hline Arbobeleid & 76 & 72 & 71 & 80 & 82 & 82 \\
\hline Lifestyleadvies ${ }^{\mathrm{a})}$ & & & & 10 & 6 & 15 \\
\hline $\begin{array}{l}\text { Leeftijdbewust en levensfasebewust personeelsbeleid } \\
\text { aiet beschikbaar voor } 2011\end{array}$ & 36 & 39 & 34 & 35 & 38 & 38 \\
\hline
\end{tabular}





\section{Bijlage B: Op oudere medewerkers gericht HR-beleid, naar sector}

\begin{tabular}{|c|c|c|c|c|c|c|}
\hline & & 2011 & & & 2012 & \\
\hline & $\begin{array}{c}\text { Overheid } \\
\%\end{array}$ & $\begin{array}{c}\text { Onderwijs } \\
\%\end{array}$ & $\begin{array}{c}\text { Overig } \\
\%\end{array}$ & $\begin{array}{c}\text { Overheid } \\
\%\end{array}$ & $\begin{array}{c}\text { Onderwijs } \\
\%\end{array}$ & $\begin{array}{c}\text { Overig } \\
\%\end{array}$ \\
\hline Aanpassing van de werkplek & 51 & 32 & 43 & 45 & 22 & 30 \\
\hline Inzetten in taken waar zij goed in zijn & 35 & 51 & 48 & 36 & 45 & 33 \\
\hline Taakverlichting & 22 & 34 & 30 & 21 & 28 & 17 \\
\hline Cursus pensioen in zicht & 30 & 13 & 19 & 29 & 16 & 16 \\
\hline Extra opleiding of cursusdeelname & 23 & 18 & 24 & 17 & 11 & 10 \\
\hline Mentorfunctie voor oudere werknemers & 11 & 22 & 18 & 11 & 14 & 12 \\
\hline Leeftijdvakantiedagen & 80 & 44 & 64 & 75 & 37 & 58 \\
\hline Seniorenverlof & 36 & 69 & 47 & 31 & 68 & 44 \\
\hline Demotie van oudere werknemers & 3 & 4 & 5 & 6 & 4 & 4 \\
\hline Teruggang in salaris & 3 & 2 & 4 & 1 & 1 & 1 \\
\hline Promotie & 15 & 15 & 15 & 9 & 7 & 12 \\
\hline Arbeidsduurverkorting & 34 & 48 & 36 & 26 & 46 & 27 \\
\hline Deeltijdpensioen & 48 & 38 & 33 & 53 & 42 & 29 \\
\hline Extra storting levensloopsparen & 23 & 12 & 17 & 17 & 11 & 13 \\
\hline Toestaan doorwerken na 65 & 21 & 21 & 26 & 27 & 23 & 33 \\
\hline Salarisgarantie & 31 & 27 & 26 & 36 & 27 & 32 \\
\hline Vertrekregelingen & 14 & 15 & 19 & 12 & 15 & 8 \\
\hline
\end{tabular}


